


\section{Orthofosfaat gehalten in varkensmest en potentieel voor terugwinning}

M. Timmerman ${ }^{1)}$, N. Verdoes ${ }^{1)}$, G.C.C. Kupers ${ }^{1)}$, R. Verheijen ${ }^{2)}$

1 Wageningen Livestock Research

2 Varkens Innovatie Centrum (VIC) Sterksel

Dit onderzoek is uitgevoerd door Wageningen Livestock Research, in opdracht van en gefinancierd door het Ministerie van Economische Zaken, in het kader van het Kennisbasisonderzoek thema 'Circular \& Biobased Economy' (projectnummer KB-26-010-002).

Wageningen Livestock Research

Wageningen, Maart 2018

Rapport 1089 
Timmerman, M., N. Verdoes, G.C.C. Kupers, R. Verheijen, 2018. Orthofosfaat gehalten in varkensmest en potentieel voor terugwinning. Wageningen Livestock Research, Rapport 1089.

Samenvatting NL In dit rapport zijn de resultaten beschreven van het onderzoek naar de orthofosfaat gehalten in (gescheiden) varkensmest en faeces. Mest van verschillende diercategorieën is verzameld en gescheiden met een vijzelpers of met een centrifuge, waarbij de mest en mestfacties werden bemonsterd en geanalyseerd op de gehalten aan orthofosfaat en totaal fosfaat. Aanvullend is de orthofosfaat in de dunne fracties afkomstig van de centrifuge geprecipiteerd m.b.v. calciumhydroxide. De orthofosfaat gehalten waren laag met uitzondering van de faeces van de biggen en vleesvarkens op droogvoer die een gehalte van ongeveer $2459 \mathrm{mg} / \mathrm{kg}$ hadden.

Summary UK This report describes the results of the research into the orthophosphate content in (separated) pig manure and faeces. Manure from several different animal categories was collected and separated with a screw press or a centrifuge, and samples were collected of the manure and fractions and analyzed on the content of available orthophosphate and total phosphate. Furthermore, the orthophosphate was extracted from the liquid fractions of the centrifuge with calcium hydroxide. The orthophosphate contents were low with the exception of the faeces of piglets and finisher pigs fed dry feed which had a content of around $2459 \mathrm{mg} / \mathrm{kg}$.

Dit rapport is gratis te downloaden op https://doi.org/10.18174/442522 of op www.wur.nl/livestock-research (onder Wageningen Livestock Research publicaties).

\section{(C) 2017 Wageningen Livestock Research}

Postbus 338, 6700 AH Wageningen, T 03174839 53, E info.livestockresearch@wur.nl, www. wur. nl/livestock-research. Wageningen Livestock Research is onderdeel van Wageningen University \& Research.

Wageningen Livestock Research aanvaardt geen aansprakelijkheid voor eventuele schade voortvloeiend uit het gebruik van de resultaten van dit onderzoek of de toepassing van de adviezen.

Alle rechten voorbehouden. Niets uit deze uitgave mag worden vermenigvuldigd en/of openbaar gemaakt worden door middel van druk, fotokopie, microfilm of op welke wijze dan ook zonder voorafgaande toestemming van de uitgever of auteur.

De certificering volgens ISO 9001 door DNV onderstreept ons kwaliteitsniveau. Op als onze onderzoeksopdrachten zijn de Algemene Voorwaarden van de Animal Sciences Group van toepassing. Deze zijn gedeponeerd bij de Arrondissementsrechtbank Zwolle. 


\section{Inhoud}

$\begin{array}{ll}\text { Samenvatting } & 5\end{array}$

$\begin{array}{lll}1 & \text { Inleiding } & 7\end{array}$

$\begin{array}{lll}1.1 & \text { Achtergrond } & 7\end{array}$

$\begin{array}{lll}1.2 & \text { Doel } & 7\end{array}$

2

$\begin{array}{lr}\text { Materiaal en Methode } & 8\end{array}$

2.1 Materiaal $\quad 8$

2.2 Monsternamemethode $\quad 8$

2.3 Analysemethode $\quad 9$

$\begin{array}{lll}2.4 & \text { Terugwinning van fosfaat uit de dunne fractie } & 10\end{array}$

3

Resultaten

11

$\begin{array}{lll}3.1 & \text { Samenstelling drijfmest } & 11\end{array}$

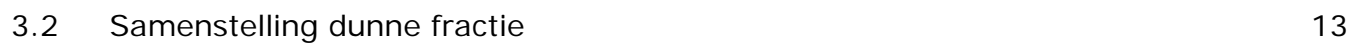

$\begin{array}{lll}3.3 & \text { Samenstelling dikke fractie } & 15\end{array}$

$\begin{array}{lll}3.4 & \text { Samenstelling faeces } & 19\end{array}$

$\begin{array}{lll}3.5 & \text { Terugwinning van fosfaat uit de dunne fractie } & 21\end{array}$

4

$\begin{array}{lr}\text { Discussie } & 22\end{array}$

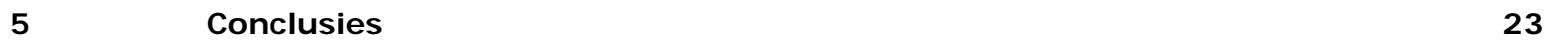

$\begin{array}{ll}\text { Literatuur } & 24\end{array}$ 



\section{Samenvatting}

De varkenshouderij heeft nadrukkelijk te maken met de fosfaatregelgeving: dierrechten, nationaal fosfaatplafond en de verplichte mestverwerking. Het overgrote deel van de bedrijven heeft een fosfaatoverschot. Het fosfaat zal verantwoord en duurzaam aangewend of afgezet moeten worden. Door een deel van de makkelijk winbare fosfaat (orthofosfaat) uit de mest te halen blijft het overige deel van de nutriënten en organische stof in mest beschikbaar voor bemesting. Hierdoor wordt varkensmest aantrekkelijker voor de akkerbouwer doordat per kg aangevoerde fosfaat meer organische stof wordt aangevoerd. Daarom is onderzoek uitgevoerd naar de beschikbaarheid van orthofosfaat in verschillende soorten (gescheiden) varkensmest.

Het onderzoek is uitgevoerd op Varkens Innovatie Centrum (VIC) Sterksel waarbij gebruik is gemaakt van een vijzelpers of een centrifuge om de varkensdrijfmest te scheiden. Om een beeld te krijgen van de variatie die optreedt in het orthofosfaat gehalte in de praktijk is de mest van verschillende diercategorieën (dragende zeugen, kraamzeugen, biggen en vleesvarkens) onderzocht, waarbij bij de vleesvarkens ook verschillende rantsoenen (droogvoer, brijvoer, gefermenteerd) zijn meegenomen in het onderzoek. Naast de drijfmest (mengsel van faeces en urine) zijn van de diercategorieën op Sterksel ook faeces verzameld. De mestmonsters zijn o.a. geanalyseerd op het gehalte aan orthofosfaat en totaal fosfaat. Verder is van dunne fracties uit de centrifuge getracht het orthofosfaat te winnen door middel van dosering van calciumhydroxide $\left(\mathrm{Ca}(\mathrm{OH})_{2}\right)$ aan de dunne fractie.

Het uitgevoerd onderzoek heeft de volgende resultaten opgeleverd:

- In de drijfmest varieerde het orthofosfaat gehalte van 69 tot $528 \mathrm{mg} / \mathrm{kg}$ en bedroeg 3,0 tot $13,7 \%$ van de totale hoeveelheid fosfaat in de drijfmest.

- In de dunne fracties afkomstig van de vijzelpers varieerde het orthofosfaat gehalte van 64 tot 517 $\mathrm{mg} / \mathrm{kg}$ en bedroeg 2,6 tot $17,1 \%$ van de totale hoeveelheid fosfaat in de dunne fractie. In de dunne fracties afkomstig van de centrifuge varieerde het orthofosfaat gehalte van 41 tot 491 $\mathrm{mg} / \mathrm{kg}$ en bedroeg 8,9 tot $53,8 \%$ van de totale hoeveelheid fosfaat in de dunne fractie.

- In de dikke fracties is het orthofosfaat gehalte berekend, omdat analyseren zonder verdunning niet mogelijk bleek. Het berekende orthofosfaat gehalte in de dikke fractie afkomstig van de vijzelpers varieerde van 98 tot $783 \mathrm{mg} / \mathrm{kg}$ en bedroeg 2,3 tot 13,2\% van de totale hoeveelheid fosfaat in de dikke fractie. In de dikke fracties afkomstig van de centrifuge varieerde het berekende orthofosfaat gehalte van 70 tot $752 \mathrm{mg} / \mathrm{kg}$ en bedroeg 0,4 tot 4,4\% van de totale hoeveelheid fosfaat in de dikke fractie.

- In de faeces was het orthofosfaat gehalte gemiddeld $67 \mathrm{mg} / \mathrm{kg}$ bij kraamzeugen en guste en dragende zeugen, en gemiddeld $2459 \mathrm{mg} / \mathrm{kg}$ bij biggen en vleesvarkens op droogvoer. De $\mathrm{pH}$ van de faeces van de biggen en vleesvarkens op droogvoer lag beneden de 5,8 terwijl dit bij de zeugen boven de 6,6 lag.

- Na toevoeging van calciumhydroxide aan dunne fracties afkomstig van de centrifuge kwam gemiddeld $9 \%$ van de massa, $37 \%$ van de droge stof, $69 \%$ van het totaal fosfaat en $63 \%$ van de orthofosfaat terecht in het sediment.

- Het orthofosfaat gehalte in de varkensmest, dunne en dikke fracties, en faeces van de zeugen was niet hoog genoeg om dit te gaan winnen uit de mest en mestfracties zonder aanvullende maatregelen, zoals aanzuren om meer orthofosfaat vrij te maken uit de aanwezig fosfaatverbindingen. Bij faeces van de biggen en vleesvarkens op varkens lag het orthofosfaat gehalte op gemiddeld $2459 \mathrm{mg} / \mathrm{kg}$ waarmee ongeveer $31 \%$ van het aanwezige fosfaat potentieel uit de faeces zou gewonnen kunnen worden. 


\section{$1 \quad$ Inleiding}

\subsection{Achtergrond}

Fosfor $(P)$ is een essentieel element voor al het leven op aarde. Het inefficiënt gebruik van fosfor, in het bijzonder in de voedselketen, leidt tot af- en uitspoeling van fosfaat naar grond- en oppervlaktewater en vormt daarmee een bedreiging voor het aquatisch milieu. Inefficiënt gebruik van fosfaat zorgt daarnaast voor uitputting van de beschikbare rots-fosfaat wat een essentiële eindige natuurlijke hulpbron is die in een beperkt aantal landen beschikbaar is. Een hogere fosfaat-efficiëntie is essentieel om fosfaat voor toekomstige generaties beschikbaar te houden en om ons milieu te beschermen. In bijlage 1 staan de fosforstromen voor Nederland en de Nederlandse landbouw weergegeven over 2011. De figuren laten zien dat in Nederland over 2011 een verlies van in totaal 23 miljoen kg P optrad, met name door het niet hergebruiken van fosfor uit zuiveringsslib van RWZI's en andere afvalstromen. In de Nederlandse landbouw gaat daarnaast nog eens 3 miljoen $\mathrm{kg} P$ verloren door uit- of afspoeling naar het grond- en oppervlaktewater en accumuleert 12 miljoen $\mathrm{kg} P$ in de bodem. Dit illustreert dat er grote verbeteringen mogelijk zijn om de fosforefficiëntie in Nederland te verhogen. De fosforefficiëntie kan worden verbeterd door het reduceren van fosfor verliezen en door hergebruik van fosfor uit reststromen (voedsel afval, dierlijke mest, menselijke mest), zonder dat dit de kwaliteit van de bodem en de voedselveiligheid negatief beïnvloedt. Dit vereist een combinatie van innovatieve en duurzame technologieën om: 1) de fosforefficiëntie op boerderijschaal en regionaal niveau te verbeteren, 2) reststromen te recyclen en 3) fosfor te winnen uit reststromen om fosfaatkunstmest en andere minerale fosfor substituten te produceren.

De varkenshouderij heeft nadrukkelijk te maken met de fosfaatregelgeving: dierrechten, nationaal fosfaatplafond en de verplichte mestverwerking. Het overgrote deel van de bedrijven heeft een fosfaatoverschot. Het fosfaat zal verantwoord en duurzaam aangewend of verwerkt moeten worden. Door een deel van de makkelijk winbare fosfaat (orthofosfaat) uit de mest te halen blijft het overige deel van de nutriënten en organische stof in mest beschikbaar voor bemesting. Hierdoor wordt varkensmest aantrekkelijker voor de akkerbouwer doordat per kg aangevoerde fosfaat meer organische stof wordt aangevoerd. Er is dus behoefte aan kennis over de verschillende fosforfracties in varkensmest om het potentieel van winning van orthofosfaat uit varkensmest te bepalen.

\subsection{Doel}

Het doel van het onderzoek was het bepalen van het orthofosfaat gehalte in verschillende soorten varkensmest, dunne en dikke fracties, en faeces. 


\section{Materiaal en Methode}

\section{$2.1 \quad$ Materiaal}

Het onderzoek is uitgevoerd op Varkens Innovatie Centrum (VIC) Sterksel met de daar aanwezige mestscheidingsinstallatie. De mestscheidingsinstallatie bestond uit een opslagsilo van $50 \mathrm{~m}^{3}$ en twee mestscheiders: een vijzelpers (Vincentcorp KP-10 S/N 08356-C) en een centrifuge (GEA Westfalia UCA 501-00-32). Bij de keuze van de varkensmest is ervoor gekozen om onderscheidende typen varkensmestsoorten te onderzoeken om zo een beeld te krijgen van de variatie die optreedt in het orthofosfaat gehalte in de praktijk. Dit is gebeurd door drijfmest van de verschillende diercategorieën (dragende zeugen, kraamzeugen, biggen en vleesvarkens) op Sterksel te gebruiken. Aangezien op Sterksel geen bijproducten werden gevoerd of voer werd gefermenteerd is er ook drijfmest aangevoerd van andere varkensbedrijven. Dit betroffen twee vleesvarkensbedrijven die brijvoer verstrekte en een vleesvarkensbedrijf die gefermenteerd voer verstrekte. Naast de drijfmest zijn van de verschillende diercategorieën (dragende zeugen, kraamzeugen, biggen en vleesvarkens) op Sterksel ook faeces verzameld. De herkomst van de mestmonsters zijn in het rapport als volgt weergegeven:

- $\quad \mathrm{GDZ}=$ Guste en dragende zeugen

- $\quad \mathrm{KRZ}=$ Kraamzeugen

- $\quad \mathrm{BIG}=$ Biggen

- $\quad \mathrm{VV}-\mathrm{DV}=$ Vleesvarkens op droogvoer

- $\quad \mathrm{VV}-\mathrm{BV} 1$ = Vleesvarkens op brijvoer van bedrijf 1

- $\quad$ VV-BV2 = Vleesvarkens op brijvoer van bedrijf 2

- $\quad$ VV-FERM = Vleesvarkens op gefermenteerd voer

De gemiddelde gehalten in het rantsoen wat werd gevoerd voorafgaand aan de monstername staat weergegeven in tabel 1, welke afkomstig waren van de rantsoenberekening van de voeradviseur. Van de twee brijvoerbedrijven zijn geen gegevens ontvangen m.b.t. de rantsoensamenstelling.

Tabel 1 Gemiddelde gehalten in het rantsoen van de verschillende diercategorieën op basis van $88 \%$ droge stof.

\begin{tabular}{|c|c|c|c|c|c|c|c|}
\hline Diercategorie & $\begin{array}{c}\text { DS } \\
(\mathrm{g} / \mathrm{kg})\end{array}$ & $\begin{array}{c}\text { Fosfor } \\
\text { (g P/ kg ds) }\end{array}$ & $\begin{array}{l}\text { Vert. fosfor } \\
\text { (g P/ kg ds) }\end{array}$ & $\begin{array}{l}\text { Ruw Eiwit } \\
\text { (g/ kg ds) }\end{array}$ & $\begin{array}{l}\text { Ruw Vet } \\
\text { (g/ kg ds) }\end{array}$ & $\begin{array}{c}\text { Ruwe } \\
\text { Celstof } \\
\text { (g/ kg ds) }\end{array}$ & $\begin{array}{l}E W \\
(-)\end{array}$ \\
\hline GDZ & 880 & 5,46 & 2,65 & 128 & 48 & 92 & 0,98 \\
\hline KRZ & 878 & 6,13 & 3,51 & 165 & 65 & 57 & 1,10 \\
\hline BIG & 882 & 5,44 & 3,49 & 170 & 53 & 46 & 1,14 \\
\hline VV-DV & 872 & 4,64 & 2,56 & 159 & 45 & 47 & 1,12 \\
\hline VV-BV1 1) & - & - & - & - & - & - & - \\
\hline VV-BV2 ${ }^{11}$ & - & - & - & - & - & - & - \\
\hline VV-FERM & 250 & 4,06 & - & 157 & 44 & 48 & 1,16 \\
\hline
\end{tabular}

1) Geen rantsoengegevens ontvangen.

\subsection{Monsternamemethode}

Van elke mestsoort is circa $36 \mathrm{~m}^{3}$ uit de mestkelder opgezogen of aangevoerd en opgeslagen in de leeggemaakte opslagsilo van de mestscheidingsinstallatie. Elke mestsoort werd voorafgaand aan de scheiding gemixt en vervolgens werd circa 8 liter drijfmest afgetapt in een schone emmer. De verzamelde mest in de emmer werd nogmaals gemengd en bemonsterd. De mest werd vervolgens eerst gescheiden met de centrifuge in een dikke en dunne fractie. Zodra de centrifuge goed was afgesteld en paar kuub was gescheiden met de goede afstelling vond de monstername plaats. Van de dikke fractie werd circa $8 \mathrm{~kg}$ verzameld in een schone emmer en daarna bemonsterd. Van de dunne fractie werd circa 8 liter opgevangen in een schone emmer en daarna werden twee monsters van circa 
0,9 liter genomen. Nadat de monsters waren genomen van de centrifuge werd overgeschakeld op de vijzelpers. Zodra de vijzelpers goed was afgesteld en paar kuub was gescheiden met de goede afstelling vond de monstername plaats. Van de dikke fractie werd circa $8 \mathrm{~kg}$ verzameld in een schone emmer en daarna werden twee monsters van circa $0,9 \mathrm{~kg}$ genomen. Van de dunne fractie werd circa 8 liter opgevangen in een schone emmer en daarna werden drie monsters van circa 0,9 liter genomen. De faeces werden verzameld in de afdelingen waar de varkens waren gehuisvest. Bij de guste en dragende zeugen werd circa $4 \mathrm{~kg}$ verse faeces verzameld van tenminste 5 verschillende zeugen. Deze faeces werden goed gemengd en vervolgens werden twee monsters van circa $0,9 \mathrm{~kg}$ genomen. Bij de kraamzeugen werd circa $4 \mathrm{~kg}$ verse faeces verzameld van tenminste 5 verschillende zeugen. Deze faeces werden goed gemengd en vervolgens werden twee monsters van circa 0,9 kg genomen. Bij de biggen werd circa $4 \mathrm{~kg}$ verse faeces verzameld van tenminste 20 verschillende biggen. Deze faeces werden goed gemengd en vervolgens werden twee monsters van circa 0,9 kg genomen. Bij de vleesvarkens werd circa $4 \mathrm{~kg}$ verse faeces verzameld van tenminste 10 verschillende vleesvarkens. Deze faeces werden goed gemengd en vervolgens werden twee monsters van circa 0,9 kg genomen. Alle monsters zijn na monstername zo snel als mogelijk in de koeling gezet en daarna in een vriescel tot aan analyse in het laboratorium.

\subsection{Analysemethode}

De drijfmest, dunne en dikke fractie en faeces zijn in het laboratorium van Wageningen Livestock Research geanalyseerd op de volgende kenmerken:

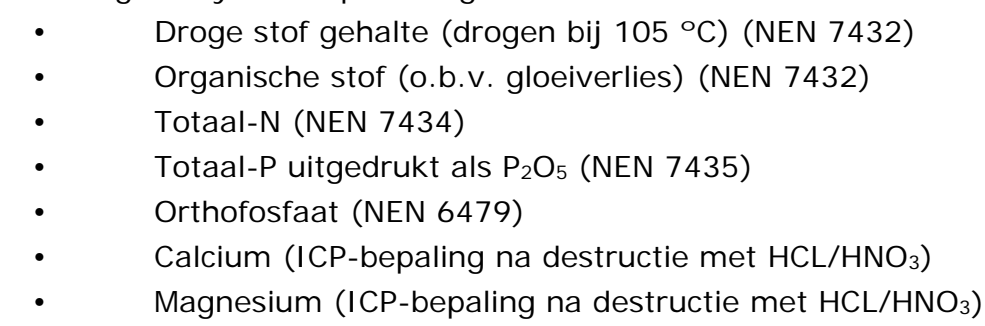

De analyseresultaten zijn uitgedrukt in gram per kilogram product tenzij anders aangegeven. Waar fosfor staat geschreven betekent dat dit uitgedrukt is in $\mathrm{P}$ en waar fosfaat staat betekent dat het uitgedrukt is in $\mathrm{P}_{2} \mathrm{O}_{5}$. Het orthofosfaat gehalte was in de dikke fractie niet zonder verdunning te bepalen. Als schatting is aangenomen dat het orthofosfaat gehalte in de waterfase van de dikke fractie gelijk is aan het gehalte in de waterfase van de dunne fractie.

Aanvullend is de $\mathrm{pH}$ van de faeces bepaald. Vanwege het droge karakter van de faeces diende er een kleine hoeveelheid water bij te worden gedaan om de $\mathrm{pH}$ te kunnen bepalen. Bij 50 gram faeces is 5 gram water gedaan wat vervolgens gemengd en gecentrifugeerd is. Van de vloeistof is de $\mathrm{pH}$ gemeten. Bij één relatief natte faeces kon de $\mathrm{pH}$ rechtstreeks worden bepaald. De $\mathrm{pH}$ zonder toevoeging van water bedroeg 5,42 en met water 5,50, een verschil van $1,5 \%$. Daarom is aangenomen dat de watertoevoeging een relatieve kleine foutmarge opleverde.

In dit onderzoek zijn de volgende drie groepen fosfaatvormen onderscheiden:

- Orthofosfaat (i.e. het daadwerkelijk opgeloste orthofosfaat $\left(\mathrm{PO}_{4}{ }^{3-}, \mathrm{HPO}_{4}{ }^{2-}\right.$, etc. ),

- Mineraal fosfaat (o.a. calciumfosfaat, struviet),

- Organisch fosfaat (o.a. fytaat, celwanden, fosfolipiden, etc.).

Het gehalte aan orthofosfaat is als volgt bepaald in de mestmonsters van de drijfmest en dunne fractie:

1. Het mestmonsters werd eerst gecentrifugeerd bij $4.500 \mathrm{rpm}$.

2. Het supernatant uit stap 1 werd vervolgens gecentrifugeerd bij $14.000 \mathrm{rpm}$.

3. Supernatant uit stap 2 werd $10 x$ verdund zo kort mogelijk voor de bepaling van het orthofosfaat gehalte.

4. Verdunde supernatant centrifugeren bij $14.000 \mathrm{rpm}$. Monsters werden niet gefiltreerd.

5. Vervolgens werd de orthofosfaat bepaald zonder destructie m.b.v. een kleuringsreactie welke specifiek is voor orthofosfaat. 


\subsection{Terugwinning van fosfaat uit de dunne fractie}

In aanvulling op de bepaling van het gehalte aan orthofosfaat in de dunne fractie is getracht het orthofosfaat uit de dunne fractie te winnen door dosering van calciumhydroxide $\left(\mathrm{Ca}(\mathrm{OH})_{2}\right)$. Deze methode is gebaseerd op het principe dat calcium met orthofosfaat neerslaat in de vorm van calciumfosfaat mineralen welke afgescheiden kunnen worden van de vloeistof. Het perspectief van deze methode is vooralsnog onbekend en hangt o.a. samen met het orthofosfaat gehalte in de dunne fractie. Daarnaast kan een deel van het fosfaat aanwezig zijn in de vorm van minerale colloïden (calciumfosfaat) en organische colloïden (o.a. fytaat). Het is onbekend in hoeverre colloïdale fosfaatvormen door middel van calciumhydroxide dosering teruggewonnen kunnen worden uit de dunne fractie. Vanwege de lage gehalten aan orthofosfaat in de dunne fracties is alleen calciumhydroxide toegevoegd aan de dunne fracties afkomstig van de centrifuge. Er is voor deze fracties gekozen omdat de centrifuge vaker wordt toegepast in de varkenshouderij en het aandeel orthofosfaat in het totaal fosfaat hoger lag en de calciumgehalten lager waren dan bij de dunne fracties afkomstig van de vijzelpers.

's Ochtends werd in een bekerglas van $800 \mathrm{ml}$ een hoeveelheid van 500 à $600 \mathrm{ml}$ dunne fractie gedaan. Aan de dunne fracties werd een overmaat calciumhydroxide ( $2 x$ zoveel op mol-basis als orthofosfaat) toegevoegd om de orthofosfaat te laten neerslaan. Vervolgens werd het mengsel circa 1 uur geroerd m.b.v. een magneetroerder. Elk 30 à 60 minuten werd visueel de mate van bezinking gecontroleerd en indien mogelijk een streepje op het bekerglas gezet wat de hoogte van het bezinksel aangaf. Afhankelijk van de mate van bezinking werd de proef aan het eind van de dag beëindigd of de volgende ochtend. Na bezinking werd het supernatant gescheiden van het sediment d.m.v.

centrifugeren. De ingaande dunne fractie, het centrifugaat en sediment zijn gewogen en geanalyseerd op: drogestof, fosfaat, orthofosfaat en $\mathrm{pH}$. Bij de uitvoering is geen controle behandeling meegenomen zonder calciumhydroxide dosering. 


\section{Resultaten}

\subsection{Samenstelling drijfmest}

In tabel 2 staan de analyseresultaten van de onderzochte drijfmesten van de verschillende diercategorieën weergegeven.

Tabel 2 Analyseresultaten van de ingaande drijfmest naar de mestscheiders per kg product.

\begin{tabular}{lccccccc} 
Mestsoort & DS & OS & $P_{2} O_{5}$ & Ortho-P $O_{5}$ & N-total & Ca \\
GDZ & $(\mathrm{g} / \mathrm{kg})$ & $(\mathrm{g} / \mathrm{kg})$ & $(\mathrm{g} / \mathrm{kg})$ & $(\mathrm{mg} / \mathrm{kg})$ & $(\mathrm{g} / \mathrm{kg})$ & $(\mathrm{g} / \mathrm{kg})$ & $(\mathrm{g} / \mathrm{kg})$ \\
\hline KRZ & 64,0 & 47,1 & 3,52 & 240 & 4,27 & 1,70 \\
\hline BIG & 47,9 & 32,3 & 1,62 & 204 & 2,34 & 0,97 & 0,51 \\
\hline VV-DV & 78,3 & 54,6 & 4,09 & 263 & 4,77 & 1,63 & 1,33 \\
\hline VV-BV1 & 90,5 & 70,8 & 3,86 & 528 & 6,92 & 1,54 & 1,09 \\
\hline VV-BV2 & 77,8 & 54,8 & 3,97 & 314 & 6,25 & 1,98 & 1,39 \\
\hline VV-FERM & 78,7 & 51,6 & 4,41 & 433 & 5,07 & 2,95 & 1,37 \\
\hline
\end{tabular}

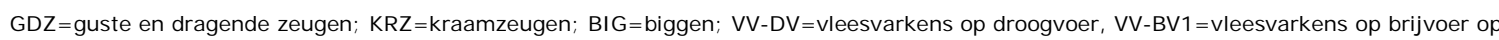
bedrijf $1 ; \mathrm{VV}$-BV2=vleesvarkens op brijvoer op bedrijf $2 ; \mathrm{VV}$-FERM=vleesvarkens op gefermenteerd voer.

De tabel laat de volgende variatie in gehalten zien in de drijfmest: fosfaat van 1,62 tot 4,09 $\mathrm{g} / \mathrm{kg}$, orthofosfaat van 69 tot $528 \mathrm{mg} / \mathrm{kg}$, aandeel van orthofosfaat t.o.v. totaal fosfaat van 3,0 tot 13,7\%, stikstof van 2,34 tot $6,92 \mathrm{~g} / \mathrm{kg}$, calcium van 0,97 tot $2,95 \mathrm{~g} / \mathrm{kg}$ en magnesium van 0,51 tot $1,39 \mathrm{~g} / \mathrm{kg}$. Het fosfaat en orthofosfaat gehalte van de vleesvarkensmest afkomstig van het bedrijf dat gefermenteerd is respectievelijk gemiddeld $43 \%$ en $84 \%$ lager dan de andere vleesvarkensmesten. Dit wordt deels veroorzaak door het lager fosforgehalte in het rantsoen $(-12,5 \%)$ en het lagere drogestofgehalte in de mest $(-23 \%)$. Het fosfaatgehalte in de mest op droge stof basis was voor de vleesvarkens op droogvoer $42,7 \mathrm{~g} / \mathrm{kg}$ ds en voor de vleesvarkens op gefermenteerd voer $36,5 \mathrm{~g} / \mathrm{kg} \mathrm{ds}$ wat een verschil is van $-12,4 \%$ wat zo goed als overeenkomt met het verschil in fosforgehalten van het rantsoen tussen beide. Echter dit verklaard niet volledig het verschil in het orthofosfaat gehalte. Het verschil kan ook niet worden verklaard door verschillen in calcium- en magnesiumgehalten. Een verschil in $\mathrm{pH}$ zal de meest waarschijnlijke oorzaak zijn.In figuur 1 staan de orthofosfaat gehalten in relatie tot de totaal fosfaatgehalten weergegeven.

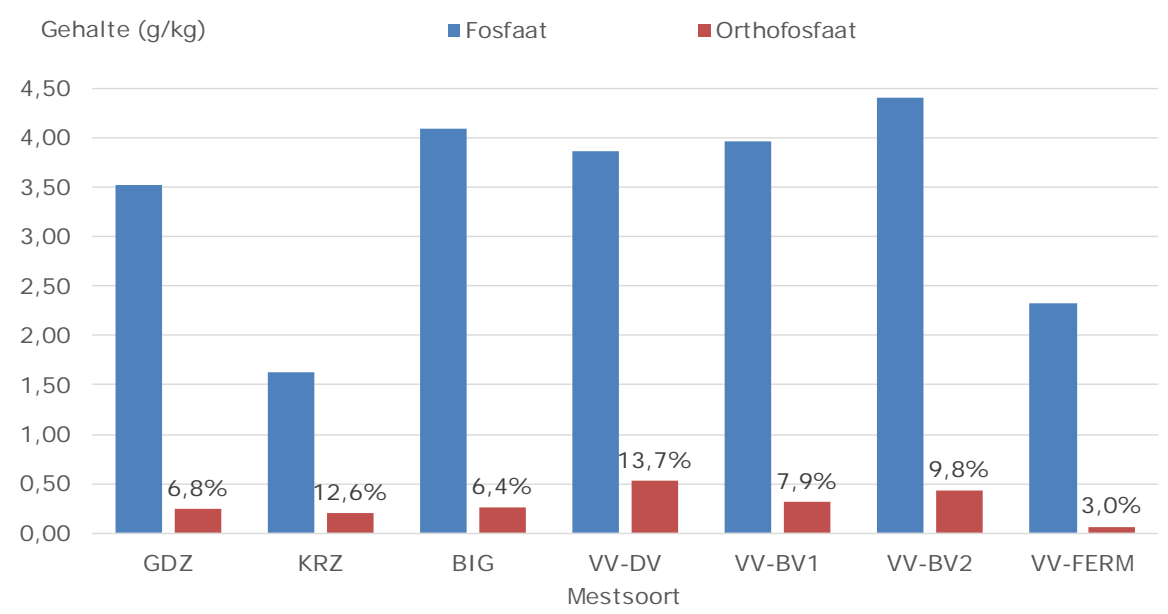

Figuur 1 Fosfaat en orthofosfaat gehalten in de drijfmest van de onderzochte varkensmestsoorten met het aandeel orthofosfaat in het totaal fosfaatgehalte.

Het orthofosfaat gehalte was het laagst in de mest van de vleesvarkens die het gefermenteerde voer kregen. De orthofosfaat gehalten in de mest van de andere vleesvarkens lagen een factor 4,5 tot 7,7 hoger. Ook het fosfaatgehalte was circa een factor 1,8 hoger in de mest van de andere vleesvarkens. Het orthofosfaat gehalte in de mest van de andere varkenscategorieën lag rond de $236 \mathrm{mg} / \mathrm{kg}$, waarbij het fosfaatgehalte in de kraamzeugenmest ruim $2 x$ zo laag was dan van de guste- en dragende zeugenmest en biggenmest. 
In figuren $2 \mathrm{a} \mathrm{t/m} \mathrm{c} \mathrm{staan} \mathrm{de} \mathrm{belangrijkste} \mathrm{relaties} \mathrm{m.b.t.} \mathrm{fosfaat,} \mathrm{orthofosfaat,} \mathrm{calcium} \mathrm{en} \mathrm{magnesium}$ in de drijfmest weergegeven met indicatieve trendlijnen. Er lijkt een zwakke relatie te zijn tussen het orthofosfaat gehalte in de mest en het totaal fosfaatgehalte in de drijfmest op product basis, terwijl dit niet het geval is op droge stof basis. Tussen het fosfaatgehalte en het calcium- en magnesiumgehalte lijkt er wel een verband te zijn. Hoe hoger het calcium- en magnesiumgehalte in de drijfmest hoe hoger het fosfaatgehalte is. Dit verband gaat niet op voor het orthofosfaat gehalte, omdat de spreiding in het orthofosfaat gehalte te groot is.
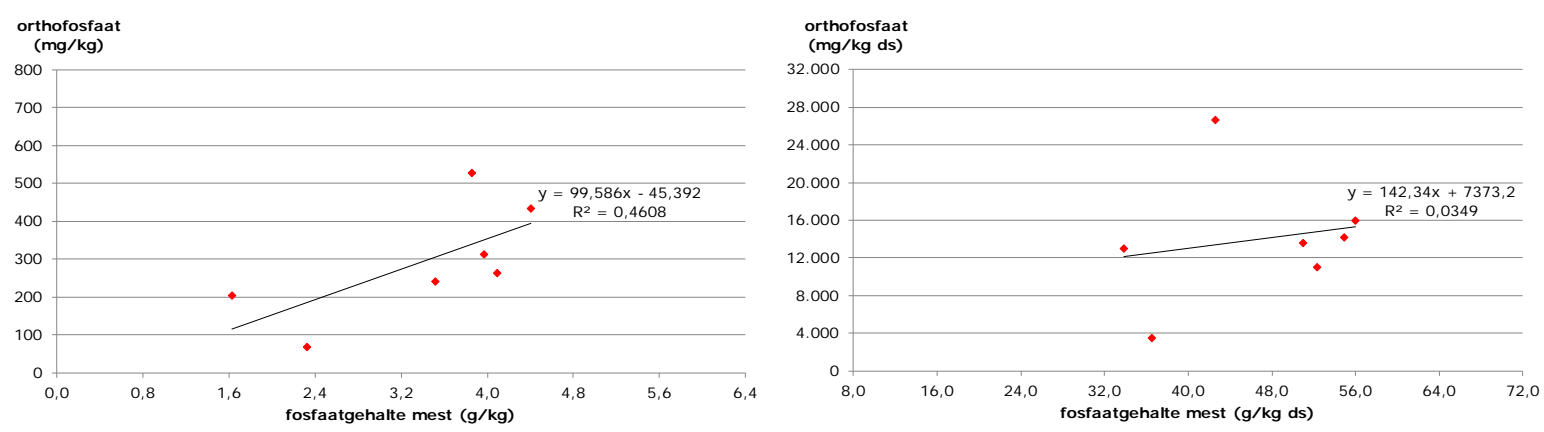

Figuur 2a Het orthofosfaat gehalte in de drijfmest in relatie tot het fosfaatgehalte in de drijfmest op product en droge stof basis.
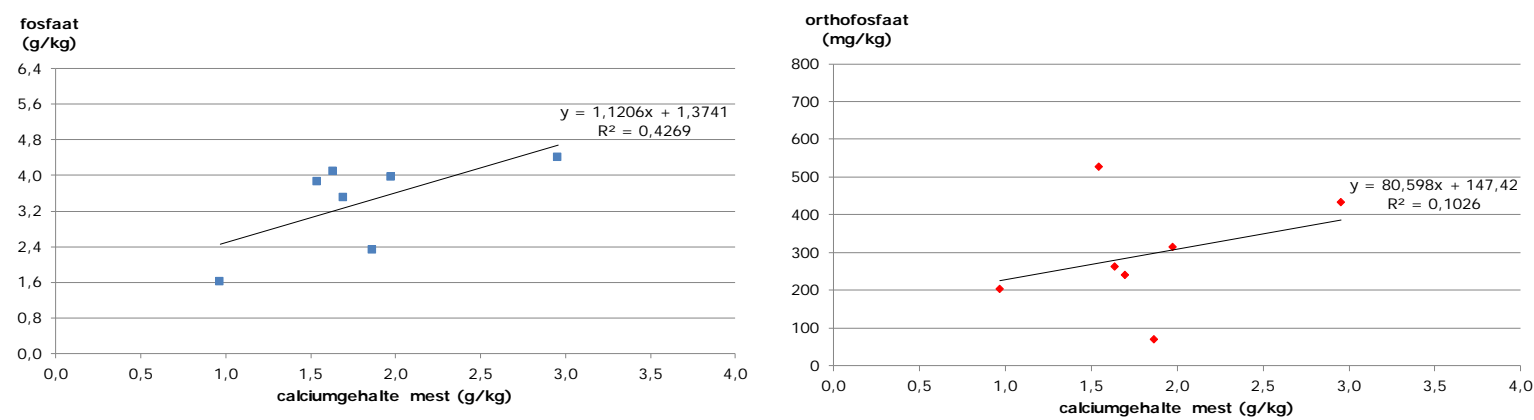

Figuur $\mathbf{2 b} \quad$ Het fosfaat en orthofosfaat gehalte in de drijfmest in relatie tot het calciumgehalte in de drijfmest.
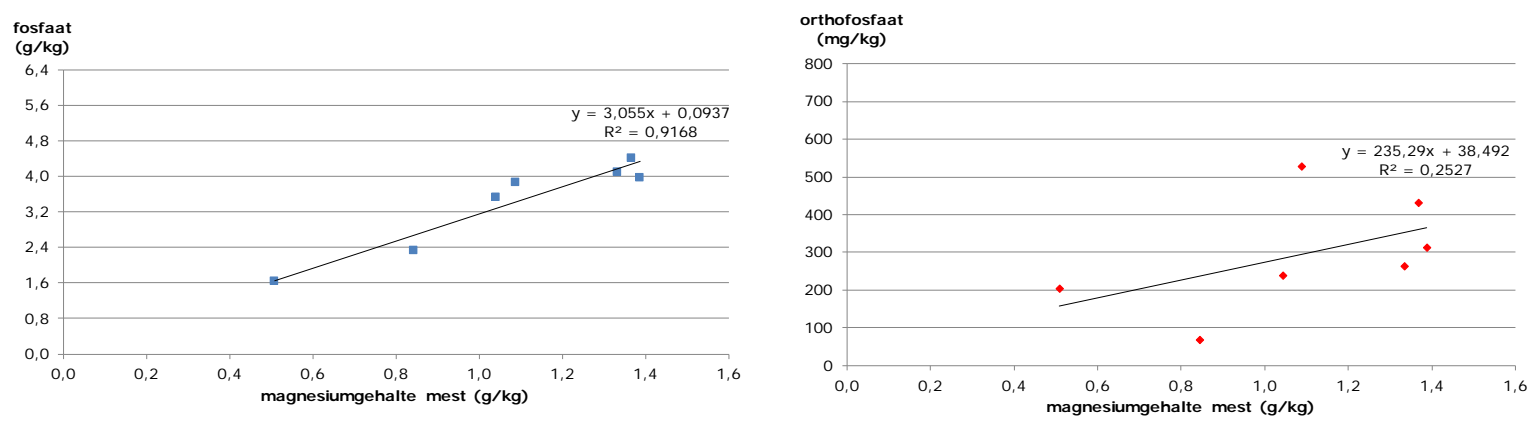

Figuur 2c Het fosfaat en orthofosfaat gehalte in de drijfmest in relatie tot het magnesiumgehalte in de drijfmest. 


\subsection{Samenstelling dunne fractie}

In tabel 3 staan de analyseresultaten van de dunne fracties afkomstig van de vijzelpers weergegeven.

Tabel 3 Analyseresultaten van de dunne fractie afkomstig van de vijzelpers per kg product.

\begin{tabular}{|c|c|c|c|c|c|c|c|}
\hline Mestsoort & $\begin{array}{c}\text { DS } \\
(\mathrm{g} / \mathrm{kg})\end{array}$ & $\begin{array}{c}\text { Os } \\
(\mathrm{g} / \mathrm{kg})\end{array}$ & $\begin{array}{c}\mathrm{P}_{2} \mathrm{O}_{5} \\
(\mathrm{~g} / \mathrm{kg})\end{array}$ & $\begin{array}{l}\text { Ortho- } \mathrm{P}_{2} \mathrm{O}_{5} \\
\text { ( } \mathrm{mg} / \mathrm{kg})\end{array}$ & $\begin{array}{l}\text { N-totaal } \\
(\mathrm{g} / \mathrm{kg})\end{array}$ & $\begin{array}{c}\mathrm{Ca} \\
(\mathrm{g} / \mathrm{kg})\end{array}$ & $\begin{array}{c}M g \\
(g / k g)\end{array}$ \\
\hline GDZ & 31,5 & 22,2 & 3,16 & 229 & 4,22 & 1,53 & 1,00 \\
\hline $\mathrm{BIG}$ & 62,2 & 39,8 & 3,87 & 255 & 4,62 & 1,51 & 1,25 \\
\hline VV-DV & 55,5 & 38,6 & 3,02 & 517 & 6,42 & 1,22 & 0,90 \\
\hline VV-BV2 & 60,8 & 34,9 & 4,10 & 440 & 4,63 & 2,73 & 1,30 \\
\hline VV-FERM & 61,1 & 41,2 & 2,43 & 64 & 5,89 & 1,84 & 0,86 \\
\hline
\end{tabular}

$\mathrm{GDZ}=$ guste en dragende zeugen; $\mathrm{KRZ}=$ kraamzeugen; $\mathrm{BIG}=$ biggen; $\mathrm{VV}$ - DV=vleesvarkens op droogvoer, $\mathrm{VV}$ - $\mathrm{BV} 1=\mathrm{vleesvarkens}$ op brijvoer op bedrijf 1; VV-BV2=vleesvarkens op brijvoer op bedrijf 2; VV-FERM=vleesvarkens op gefermenteerd voer.

De tabel laat de volgende variatie in gehalten zien in de dunne fracties van de vijzelpers: fosfaat van 2,43 tot $4,10 \mathrm{~g} / \mathrm{kg}$, orthofosfaat van 64 tot $517 \mathrm{mg} / \mathrm{kg}$, aandeel van orthofosfaat t.o.v. totaal fosfaat van 2,6 tot $17,1 \%$, stikstof van 3,51 tot $6,42 \mathrm{~g} / \mathrm{kg}$, calcium van 1,22 tot $2,73 \mathrm{~g} / \mathrm{kg}$, magnesium van 0,86 tot $1,30 \mathrm{~g} / \mathrm{kg}$. Net zoals bij de ingaande drijfmest was het fosfaat en orthofosfaat gehalte in de dunne fractie van vleesvarkens op gefermenteerd voer lager dan van overige vleesvarkensmesten. In figuur 3 staat het orthofosfaat-gehalte in relatie tot het fosfaatgehalte weergegeven in de dunne fracties afkomstig van de vijzelpers.

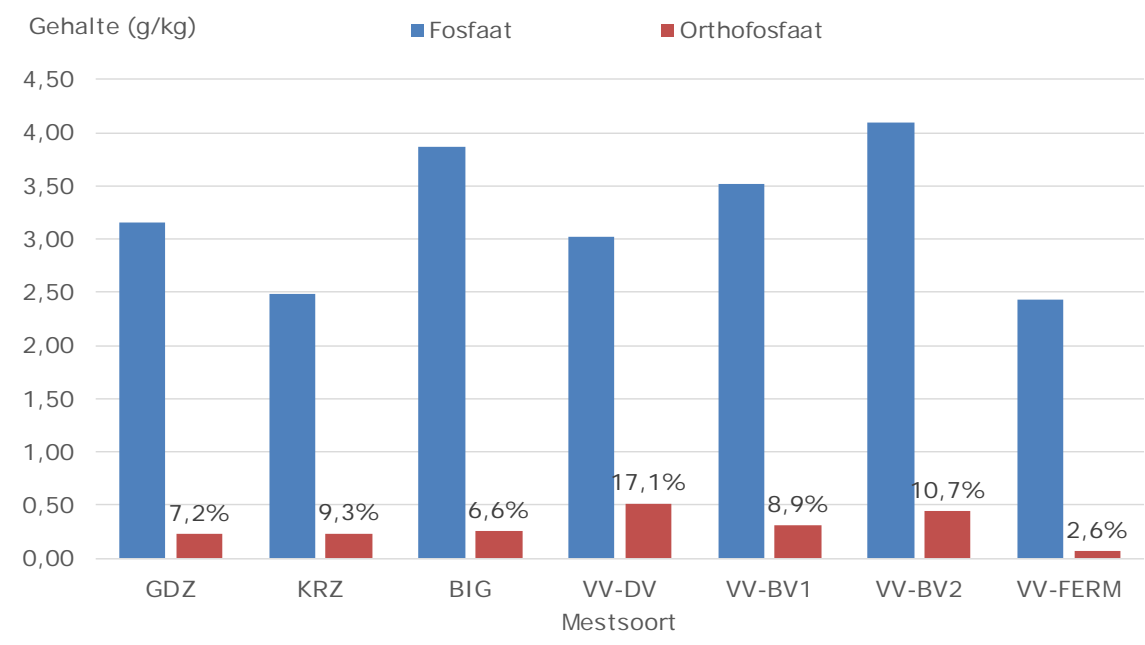

Figuur 3 Fosfaat en orthofosfaat gehalten in de dunne fracties van de vijzelpers met het aandeel orthofosfaat in het totaal fosfaatgehalte.

De orthofosfaat gehalten in de dunne fracties afkomstig van de vijzelpers verschilde weinig van de ingaande drijfmest en lagen op vergelijkbare hoogte. Net zoals bij de ingaande drijfmest was het orthofosfaat gehalte het laagst in de dunne fractie van de vleesvarkens die het gefermenteerde voer kregen. De gehalten in de dunne fracties van de andere vleesvarkens lagen een factor 4,9 tot 8,1 hoger. Ook het fosfaatgehalte was circa een factor 1,4 hoger in de dunne fracties van de andere vleesvarkens. Het orthofosfaat gehalte in de dunne fracties van de andere varkenscategorieën lag rond de $238 \mathrm{mg} / \mathrm{kg}$.

In tabel 4 staan de analyseresultaten van de dunne fracties afkomstig van de centrifuge weergegeven. 
Tabel 4 Analyseresultaten van de dunne fractie afkomstig van de centrifuge per kg product.

\begin{tabular}{lccccccc} 
Mestsoort & DS & OS & $P_{2} \mathrm{O}_{5}$ & Ortho- $\mathrm{P}_{5}$ & N-total & Ca \\
GDZ & $(\mathrm{g} / \mathrm{kg})$ & $(\mathrm{g} / \mathrm{kg})$ & $(\mathrm{g} / \mathrm{kg})$ & $(\mathrm{mg} / \mathrm{kg})$ & $(\mathrm{g} / \mathrm{kg})$ & $(\mathrm{g} / \mathrm{kg})$ & $(\mathrm{g} / \mathrm{kg})$ \\
\hline KRZ & 20,8 & 13,2 & 0,53 & 216 & 3,31 & 0,48 & 0,06 \\
\hline BIG & 14,4 & 9,0 & 0,37 & 147 & 2,18 & 0,34 & 0,06 \\
\hline VV-DV & 33,2 & 20,4 & 0,76 & 232 & 3,63 & 0,63 & 0,12 \\
\hline VV-BV1 & 38,7 & 27,2 & 0,91 & 491 & 5,91 & 0,59 & 0,08 \\
\hline VV-BV2 & 31,3 & 17,8 & 0,54 & 281 & 4,92 & 0,44 & 0,07 \\
\hline VV-FERM & 31,1 & 16,3 & 0,97 & 431 & 3,79 & 0,76 & 0,08 \\
\hline
\end{tabular}

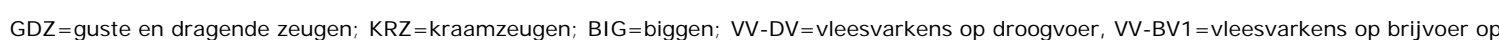
bedrijf 1 ; VV-BV2 =vleesvarkens op brijvoer op bedrijf 2; VV-FERM=vleesvarkens op gefermenteerd voer.

De tabel laat de volgende variatie in gehalten zien in de dunne fracties van de centrifuge: fosfaat van 0,47 tot $0,97 \mathrm{~g} / \mathrm{kg}$, orthofosfaat van 41 tot $491 \mathrm{mg} / \mathrm{kg}$, aandeel van orthofosfaat t.o.v. totaal fosfaat van 8,9 tot $53,8 \%$, stikstof van 2,18 tot $5,91 \mathrm{~g} / \mathrm{kg}$, calcium van 0,34 tot $0,95 \mathrm{~g} / \mathrm{kg}$, magnesium van 0,06 tot $0,16 \mathrm{~g} / \mathrm{kg}$. Net zoals bij de ingaande drijfmest was het fosfaat en orthofosfaat gehalte in de dunne fractie van vleesvarkens op gefermenteerd voer lager dan van overige vleesvarkensmesten. In figuur 3 staat het orthofosfaat-gehalte in relatie tot het fosfaatgehalte weergegeven in de dunne fracties afkomstig van de centrifuge.

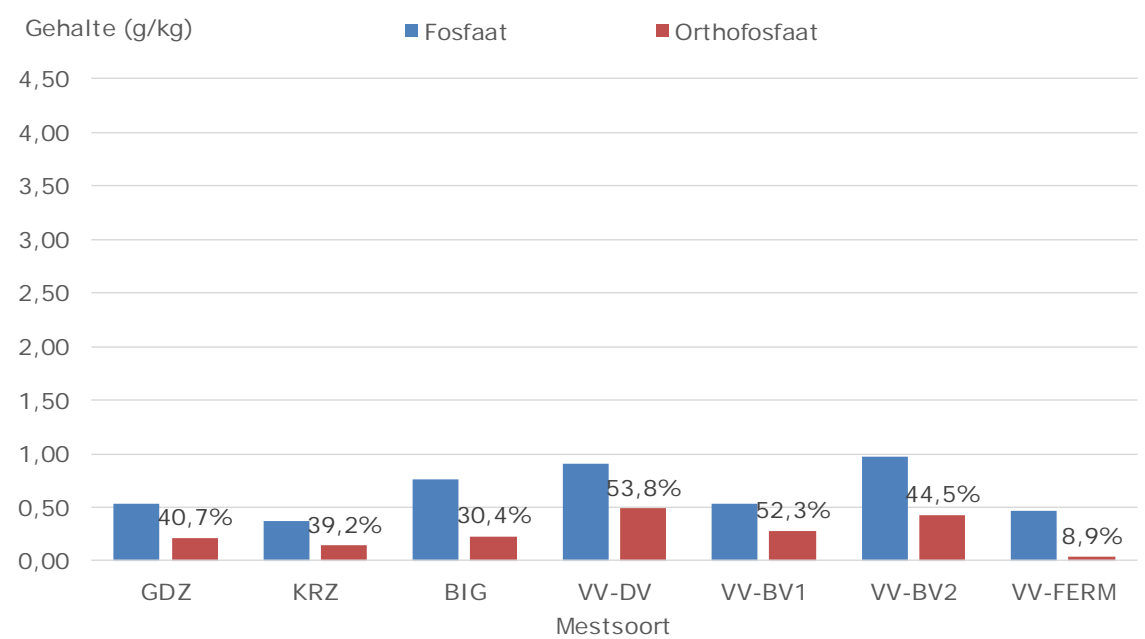

Figuur 4 Fosfaat en orthofosfaat gehalten in de dunne fracties van de centrifuge met het aandeel orthofosfaat in het totaal fosfaatgehalte.

De orthofosfaat gehalten in de dunne fracties afkomstig van de centrifuge lagen gemiddeld $10 \%$ lager dan van de ingaande drijfmest. Net zoals bij de ingaande drijfmest was het orthofosfaat gehalte het laagst in de dunne fractie van de vleesvarkens die het gefermenteerde voer kregen. De gehalten in de dunne fracties van de andere vleesvarkens lagen een factor 6,8 tot 12,0 hoger. Het fosfaatgehalte was een factor 1,1 tot 2,1 hoger in de dunne fractie van de andere vleesvarkens. Het orthofosfaat gehalte in de dunne fractie van de andere varkenscategorieën lag rond de $198 \mathrm{mg} / \mathrm{kg}$. Door het hoge scheidingsrendement voor fosfaat van een centrifuge lagen de fosfaatgehalten in de dunne fracties gemiddeld $80 \%$ lager dan van de ingaande drijfmest. Aangezien het orthofosfaat gehalte gemiddeld slechts $10 \%$ lager was, steeg het aandeel orthofosfaat in het totale fosfaat naar gemiddeld $39 \%$.

In figuren $5 \mathrm{a}$ t/m d staan de belangrijkste relaties m.b.t. fosfaat, orthofosfaat, calcium en magnesium in de dunne fracties weergegeven met indicatieve trendlijnen. Er lijkt sprake te zijn van een verband tussen het fosfaatgehalte in de dunne fracties en het fosfaatgehalte in de drijfmest voor zowel de vijzelpers als de centrifuge. Er lijkt ook een redelijke relatie te zijn tussen het orthofosfaat gehalte in de dunne fractie met het fosfaatgehalte in de ingaande mest en de dunne fractie. Tussen het fosfaatgehalte en het calcium- en magnesiumgehalte lijkt er een verband te zijn voor de vijzelpers, maar niet voor de centrifuge. Hoe hoger het calcium- en magnesiumgehalte in de dunne fractie van de vijzelpers hoe hoger het fosfaatgehalte is. Dit verband gaat niet op voor het orthofosfaat gehalte, omdat de spreiding in het orthofosfaat gehalte te groot is. 


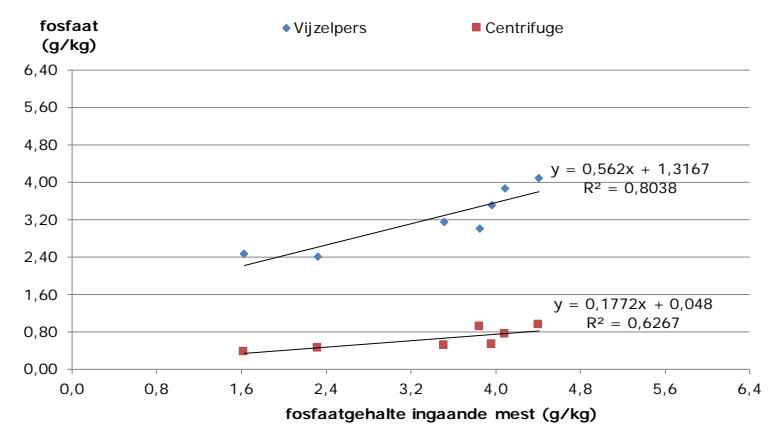

Figuur 5a Fosfaatgehalte in de dunne fractie in relatie tot het fosfaatgehalte in de ingaande mest.
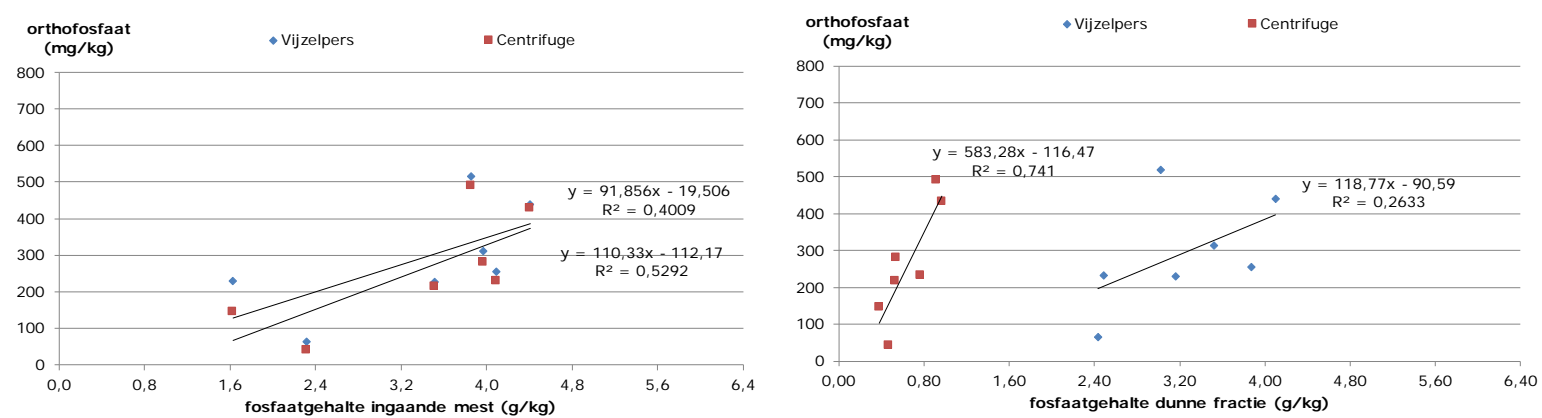

Figuur 5b Het orthofosfaat gehalte in de dunne fractie in relatie tot het fosfaatgehalte in de ingaande mest (links) en het fosfaatgehalte in de dunne fractie (rechts).
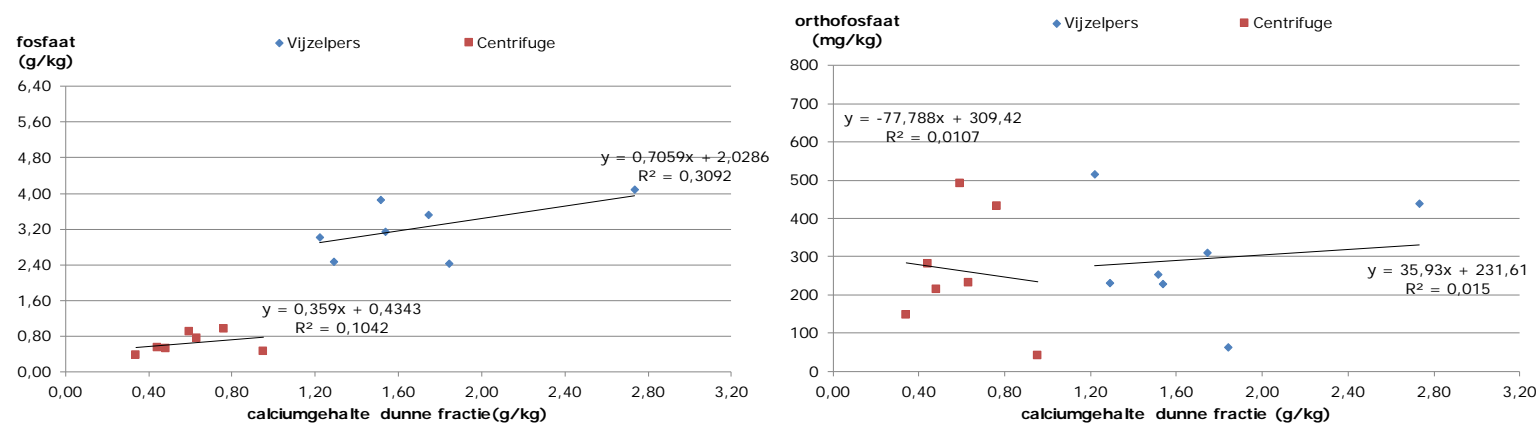

Figuur 5c Het fosfaat en orthofosfaat gehalten in de dunne fractie in relatie tot het calciumgehalte in de dunne fractie.
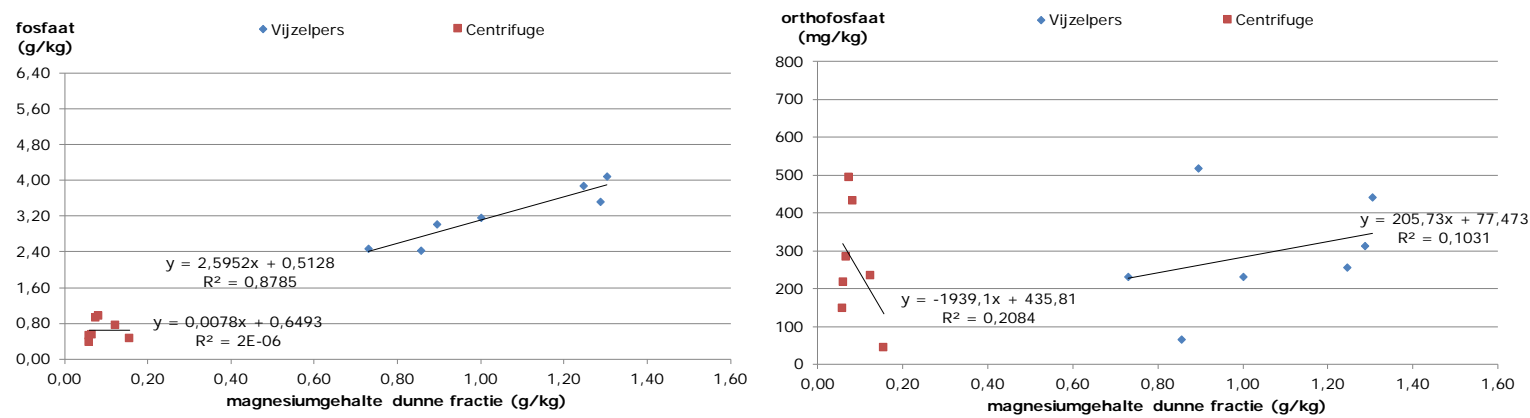

Figuur 5d Het fosfaat en orthofosfaat gehalte in de dunne fractie in relatie tot het magnesiumgehalte in de dunne fractie.

\subsection{Samenstelling dikke fractie}

In tabel 5 staan de analyseresultaten van de dikke fractie afkomstig van de vijzelpers weergegeven. 
Tabel 5 Analyseresultaten van de dikke fractie afkomstig van de vijzelpers per kg product.

\begin{tabular}{lccccccc} 
Mestsoort & DS & OS & $P_{2} O_{5}$ & Ortho- $P_{2} \mathrm{O}_{5}{ }^{1)}$ & N & Ca \\
GDZ & $(\mathrm{g} / \mathrm{kg})$ & $(\mathrm{g} / \mathrm{kg})$ & $(\mathrm{g} / \mathrm{kg})$ & $(\mathrm{mg} / \mathrm{kg})$ & $(\mathrm{g} / \mathrm{kg})$ & $(\mathrm{g} / \mathrm{kg})$ & $(\mathrm{g} / \mathrm{kg})$ \\
\hline KRZ & 292 & 258 & 7,22 & 383 & 7,20 & 4,84 & 2,06 \\
\hline BIG & 265 & 211 & 8,34 & 404 & 7,36 & 6,44 & 2,24 \\
\hline VV-DV & 276 & 234 & 7,08 & 450 & 6,25 & 4,06 & 2,01 \\
\hline VV-BV1 & 302 & 264 & 8,01 & 875 & 8,54 & 4,98 & 2,05 \\
\hline VV-BV2 & 250 & 214 & 6,02 & 568 & 7,72 & 5,13 & 1,89 \\
\hline VV-FERM & 270 & 222 & 5,95 & 783 & 6,69 & 7,83 & 1,87 \\
\hline
\end{tabular}

$\mathrm{GDZ}=$ guste en dragende zeugen; $\mathrm{KRZ}=\mathrm{kraamzeugen;} \mathrm{BI} \mathrm{G}=$ biggen; $\mathrm{VV}$ - $\mathrm{DV}=\mathrm{vleesvarkens}$ op droogvoer, $\mathrm{VV}$ - $\mathrm{BV} 1=\mathrm{vleesvarkens}$ op brijvoer op bedrijf $1 ; \mathrm{VV}$-BV2=vleesvarkens op brijvoer op bedrijf 2; VV-FERM=vleesvarkens op gefermenteerd voer.

1) Het orthofosfaat gehalte was in de dikke fractie niet zonder verdunning te bepalen. Als schatting is aangenomen dat het orthofosfaat gehalte in de waterfase van de dikke fractie gelijk is aan het gehalte in de waterfase van de dunne fractie.

De tabel laat de volgende variatie in gehalten zien in de dikke fracties van de vijzelpers: fosfaat van 4,18 tot $8,34 \mathrm{~g} / \mathrm{kg}$, het berekende orthofosfaat van 98 tot $783 \mathrm{mg} / \mathrm{kg}$, berekende aandeel van orthofosfaat t.o.v. totaal fosfaat van 2,3 tot $13,2 \%$, stikstof van 6,25 tot $8,54 \mathrm{~g} / \mathrm{kg}$, calcium van 4,06 tot $7,83 \mathrm{~g} / \mathrm{kg}$, magnesium van 1,32 tot $2,24 \mathrm{~g} / \mathrm{kg}$. In figuur 6 staat het berekende orthofosfaatgehalte in relatie tot het fosfaatgehalte weergegeven in de dikke fracties afkomstig van de vijzelpers.

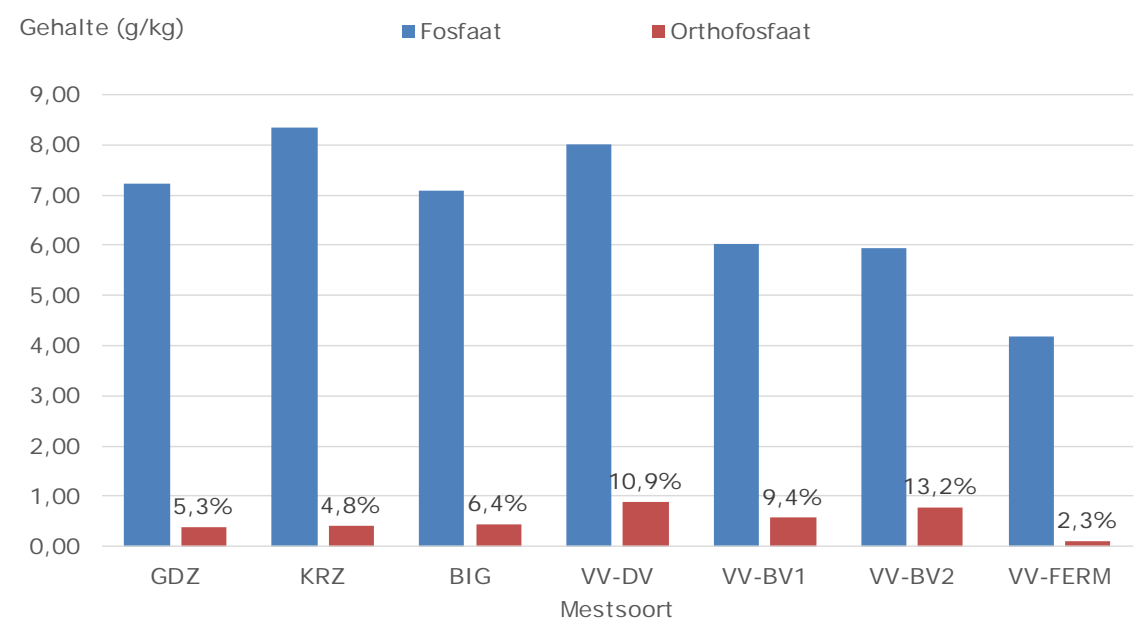

Figuur 6 Fosfaat en berekende orthofosfaat gehalten in de dikke fracties van de vijzelpers met het berekende aandeel orthofosfaat in het totaal fosfaatgehalte.

Net zoals bij de ingaande drijfmest was het berekende orthofosfaat gehalte het laagst in de dikke fractie van de vleesvarkens die het gefermenteerde voer kregen. De berekende orthofosfaat gehalten in de dikke fracties van de andere vleesvarkens lagen een factor 5,8 tot 8,9 hoger. Het fosfaatgehalte was een factor 1,4 tot 1,9 hoger in de dikke fractie van de andere vleesvarkens. Het berekende orthofosfaat gehalte in de dikke fractie van de andere varkenscategorieën lag rond de $410 \mathrm{mg} / \mathrm{kg}$.

In tabel 6 staan de analyseresultaten van de dikke fractie afkomstig van de centrifuge weergegeven. 
Tabel 6 Analyseresultaten van de dikke fractie afkomstig van de centrifuge per kg product.

\begin{tabular}{|c|c|c|c|c|c|c|c|}
\hline Mestsoort & $\begin{array}{c}\text { DS } \\
(\mathrm{g} / \mathrm{kg})\end{array}$ & $\begin{array}{c}\text { OS } \\
(\mathrm{g} / \mathrm{kg})\end{array}$ & $\begin{array}{c}\mathrm{P}_{2} \mathrm{O}_{5} \\
(\mathrm{~g} / \mathrm{kg})\end{array}$ & $\begin{array}{l}\text { Ortho- } \mathrm{P}_{2} \mathrm{O}_{5}{ }^{1)} \\
\text { ( } \mathrm{mg} / \mathrm{kg})\end{array}$ & $\begin{array}{c}N \\
(\mathrm{~g} / \mathrm{kg})\end{array}$ & $\begin{array}{c}\mathrm{Ca} \\
(\mathrm{g} / \mathrm{kg})\end{array}$ & $\begin{array}{c}M g \\
(\mathrm{~g} / \mathrm{kg})\end{array}$ \\
\hline GDZ & 313 & 236 & 22,15 & 347 & 11,78 & 8,58 & 7,55 \\
\hline $\mathrm{BIG}$ & 330 & 240 & 22,33 & 368 & 11,12 & 8,46 & 7,82 \\
\hline VV-DV & 357 & 293 & 17,27 & 752 & 11,36 & 6,57 & 5,20 \\
\hline VV-BV2 & 303 & 215 & 18,93 & 710 & 10,75 & 14,78 & 6,97 \\
\hline VV-FERM & 295 & 223 & 19,79 & 70 & 11,80 & 11,18 & 7,30 \\
\hline
\end{tabular}

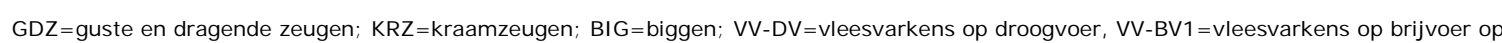
bedrijf 1; VV-BV2=vleesvarkens op brijvoer op bedrijf 2; VV-FERM=vleesvarkens op gefermenteerd voer.

1) Het orthofosfaat gehalte was in de dikke fractie niet zonder verdunning te bepalen. Als schatting is aangenomen dat het orthofosfaat gehalte in de waterfase van de dikke fractie gelijk is aan het gehalte in de waterfase van de dunne fractie.

De tabel laat de volgende variatie in gehalten zien in de dikke fracties van de centrifuge: fosfaat van 17,27 tot $22,33 \mathrm{~g} / \mathrm{kg}$, het berekende orthofosfaat van 70 tot $752 \mathrm{mg} / \mathrm{kg}$, berekende aandeel van orthofosfaat t.o.v. totaal fosfaat van 0,4 tot $4,4 \%$, stikstof van 10,63 tot $11,89 \mathrm{~g} / \mathrm{kg}$, calcium van 6,57 tot $14,78 \mathrm{~g} / \mathrm{kg}$, magnesium van 5,20 tot $7,82 \mathrm{~g} / \mathrm{kg}$. Het fosfaatgehalte in de dikke fractie van de centrifuge varieerde van 17,27 tot $22,33 \mathrm{~g} / \mathrm{kg}$ en is gemiddeld twee tot drie keer hoger dan de dikke fractie uit de vijzelpers. In figuur 7 staat het berekende orthofosfaat-gehalte in relatie tot het fosfaatgehalte weergegeven in de dikke fracties afkomstig van de centrifuge.

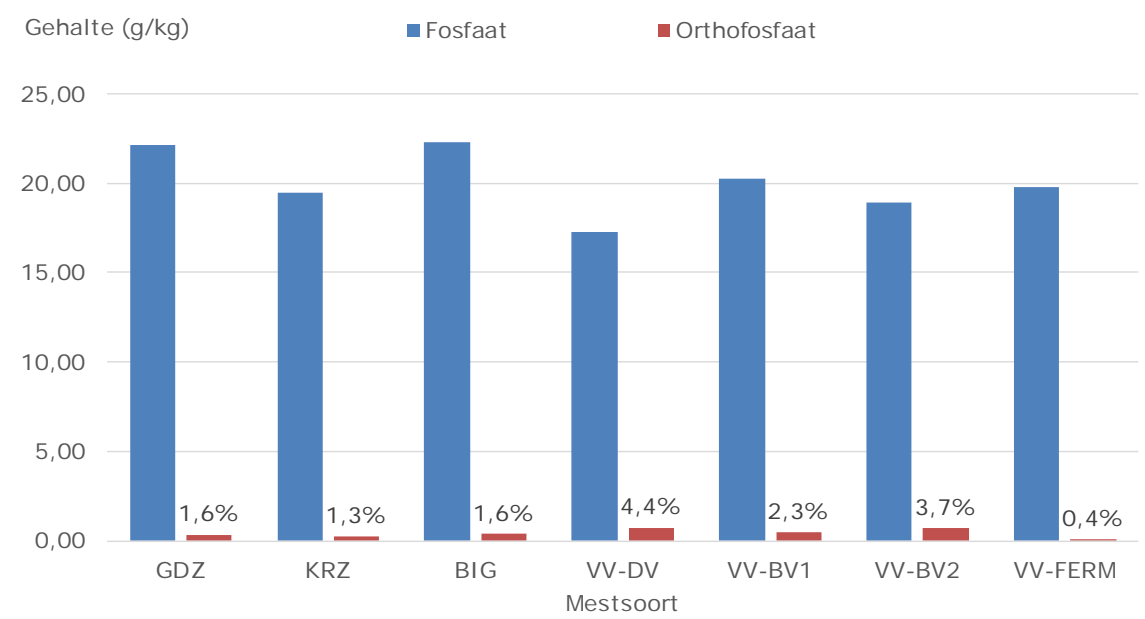

Figuur 7 Fosfaat en berekende orthofosfaat gehalten in de dikke fracties van de centrifuge met het berekende aandeel orthofosfaat in het totaal fosfaatgehalte.

De berekende orthofosfaat gehalten in dikke fractie van de centrifuge zijn lager dan de berekende orthofosfaat gehalten in de dikke fractie van de vijzelpers. Net zoals bij de ingaande drijfmest was het berekende orthofosfaat gehalte het laagst in de dikke fractie van de vleesvarkens die het gefermenteerde voer kregen. De berekende orthofosfaat gehalten in de dikke fracties van de andere vleesvarkens lagen een factor 6,6 tot 10,7 hoger. Het fosfaatgehalte lag op een vergelijkbaar niveau als in de dikke fractie van de andere vleesvarkens. Het berekende orthofosfaat gehalte in de dikke fractie van de andere varkenscategorieën lag rond de $320 \mathrm{mg} / \mathrm{kg}$. Door de hoge fosfaatgehalten in de dikke fracties afkomstig van de centrifuge is het aandeel van de orthofosfaat in de totaal fosfaat minder als $5 \%$. In figuren $8 \mathrm{at} / \mathrm{m}$ d staan de belangrijkste relaties m.b.t. fosfaat, orthofosfaat, calcium en magnesium in de dikke fracties weergegeven met indicatieve trendlijnen. Er lijkt een bepaalde mate van een relatie te zijn tussen het orthofosfaat gehalte in de dikke fractie met het fosfaatgehalte in de ingaande mest, maar niet met het fosfaatgehalte in de dikke fractie. Tussen het fosfaatgehalte en het berekende orthofosfaat gehalte en het calciumgehalte lijkt er geen verband te zijn. Er blijkt wel sprake te zijn van een verband tussen fosfaatgehalte en het magnesiumgehalte in de dikke fractie, maar dit gaat niet op voor het orthofosfaat- en het magnesiumgehalte. 


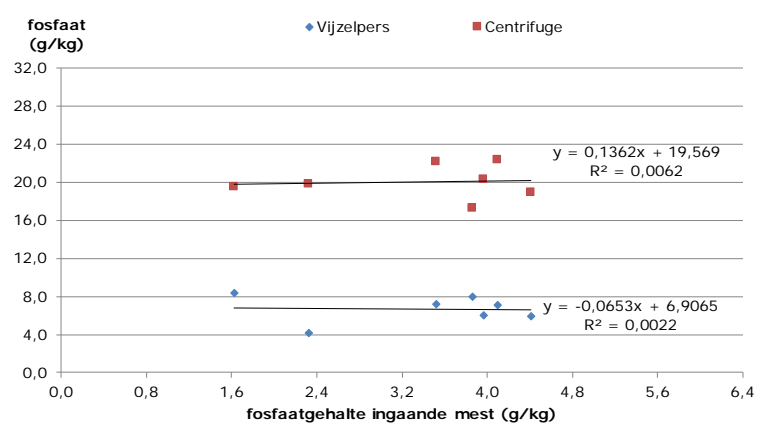

Figuur 8a Fosfaatgehalte in de dikke fractie in relatie tot het fosfaatgehalte in de ingaande mest.
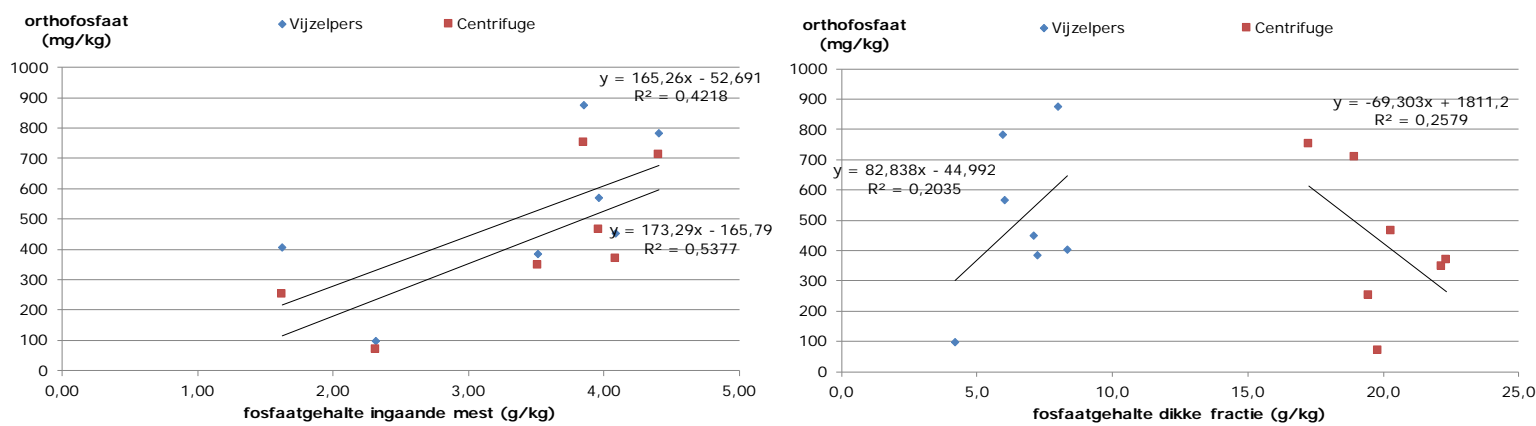

Figuur 8b Het orthofosfaat gehalte in de dikke fractie in relatie tot het fosfaatgehalte in de ingaande mest (links) en het fosfaatgehalte in de dikke fractie (rechts).
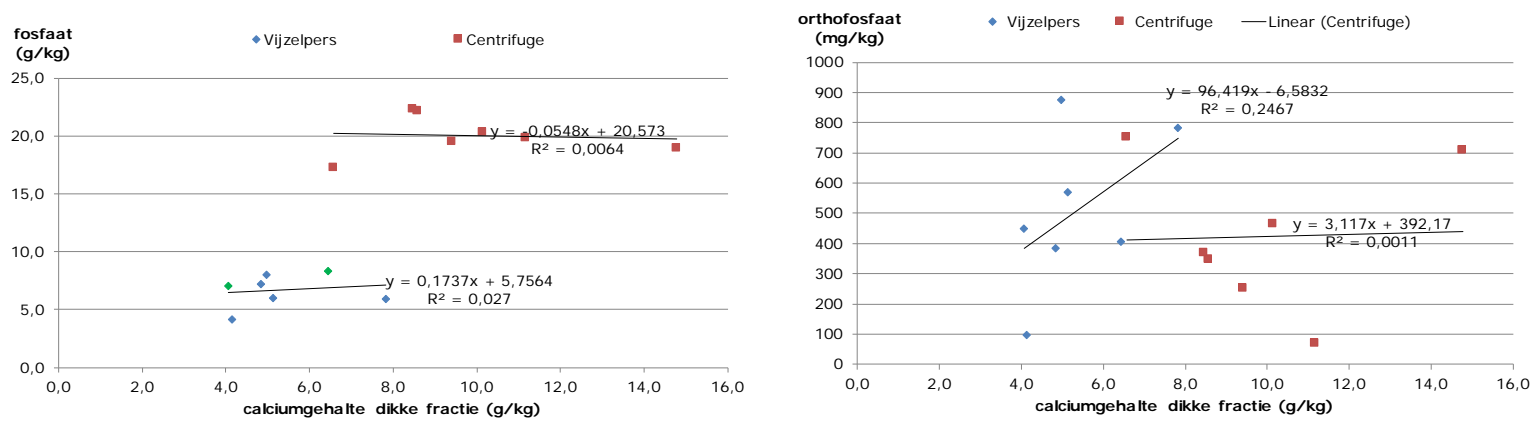

Figuur 8c Het fosfaat en orthofosfaat gehalte in de dikke fractie in relatie tot het calciumgehalte in de dikke fractie.
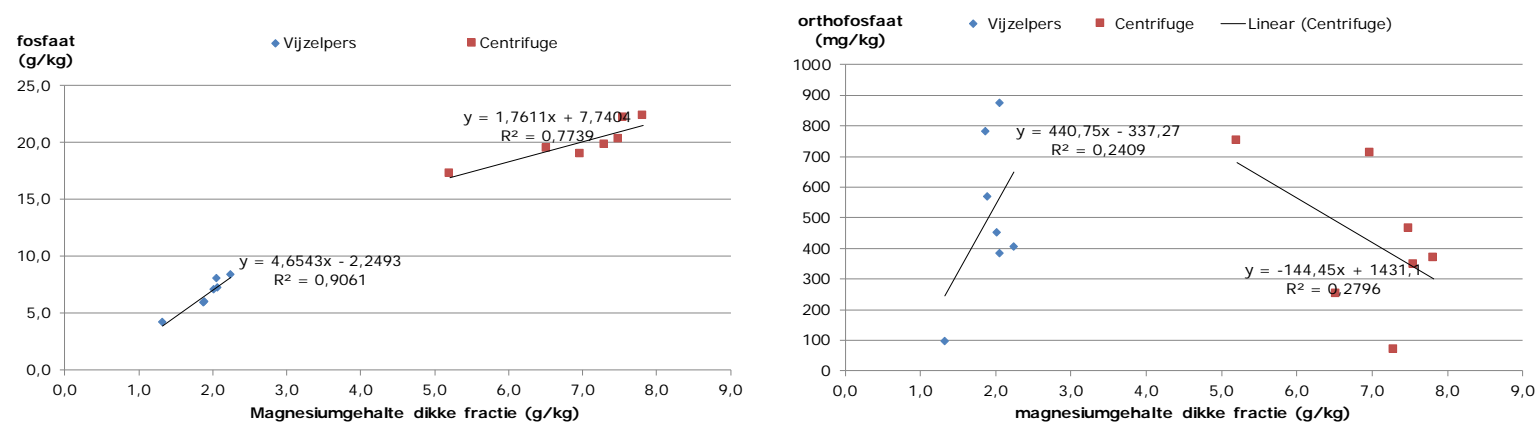

Figuur 8d Het fosfaat en orthofosfaat gehalte in de dikke fractie in relatie tot het magnesiumgehalte in de dikke fractie. 


\subsection{Samenstelling faeces}

In tabel 7 staan de analyseresultaten van de faeces weergegeven.

Tabel 7 Analyseresultaten van de faeces per kg product.

\begin{tabular}{|c|c|c|c|c|c|c|c|c|}
\hline Mestsoort & $\begin{array}{c}\text { DS } \\
(\mathrm{g} / \mathrm{kg})\end{array}$ & $\begin{array}{c}\text { Os } \\
(\mathrm{g} / \mathrm{kg})\end{array}$ & $\begin{array}{c}\mathrm{P}_{2} \mathrm{O}_{5} \\
(\mathrm{~g} / \mathrm{kg})\end{array}$ & $\begin{array}{l}\text { Ortho- } \mathrm{P}_{2} \mathrm{O}_{5} \\
(\mathrm{mg} / \mathrm{kg})\end{array}$ & $\begin{array}{c}\text { N-totaal } \\
(\mathrm{g} / \mathrm{kg})\end{array}$ & $\begin{array}{c}\mathrm{Ca} \\
(\mathrm{g} / \mathrm{kg})\end{array}$ & $\begin{array}{c}M g \\
(g / k g)\end{array}$ & $\begin{array}{l}\mathrm{pH} \\
(-)\end{array}$ \\
\hline GDZ & 307 & 253 & 13,60 & 60 & 8,56 & 8,73 & 3,64 & 7,83 \\
\hline $\mathrm{BIG}$ & 262 & 229 & 7,06 & $2.544^{1)}$ & 9,70 & 1,79 & 2,80 & 5,50 \\
\hline VV-DV & 274 & 237 & 8,90 & $2.373^{1)}$ & 8,95 & 4,13 & 2,91 & 5,80 \\
\hline
\end{tabular}

$\mathrm{GDZ}=$ guste en dragende zeugen; $\mathrm{KRZ}=\mathrm{kraamzeugen;} \mathrm{BIG=biggen;} \mathrm{V}$-DV=vleesvarkens op droogvoer

1) Heranalyse gaf hetzelfde resultaat

De tabel laat de volgende variatie in gehalten zien in de faeces: fosfaat van 7,06 tot 16,03 $\mathrm{g} / \mathrm{kg}$, het orthofosfaat van 60 tot $2.544 \mathrm{mg} / \mathrm{kg}$, aandeel van orthofosfaat t.o.v. totaal fosfaat van 0,4 tot 36,0\%, stikstof van 7,35 tot $9,70 \mathrm{~g} / \mathrm{kg}$, calcium van 1,79 tot $11,62 \mathrm{~g} / \mathrm{kg}$, magnesium van 2,80 tot $3,83 \mathrm{~g} / \mathrm{kg}$. De kraamzeugen hadden een hoog fosfaatgehalte in de faeces, terwijl het fosfaatgehalte in de drijfmest laag was. Dit zal veroorzaakt worden door een hoog gebruik aan drink- en schoonmaakwater in de kraamstal. De faeces met de laagste $\mathrm{pH}$ heeft het hoogste orthofosfaat gehalte, terwijl de faeces met de hoogste $\mathrm{pH}$ het laagste orthofosfaat gehalte heeft. In figuur 9 staat het orthofosfaat gehalte in relatie tot het fosfaatgehalte in de faeces weergegeven.

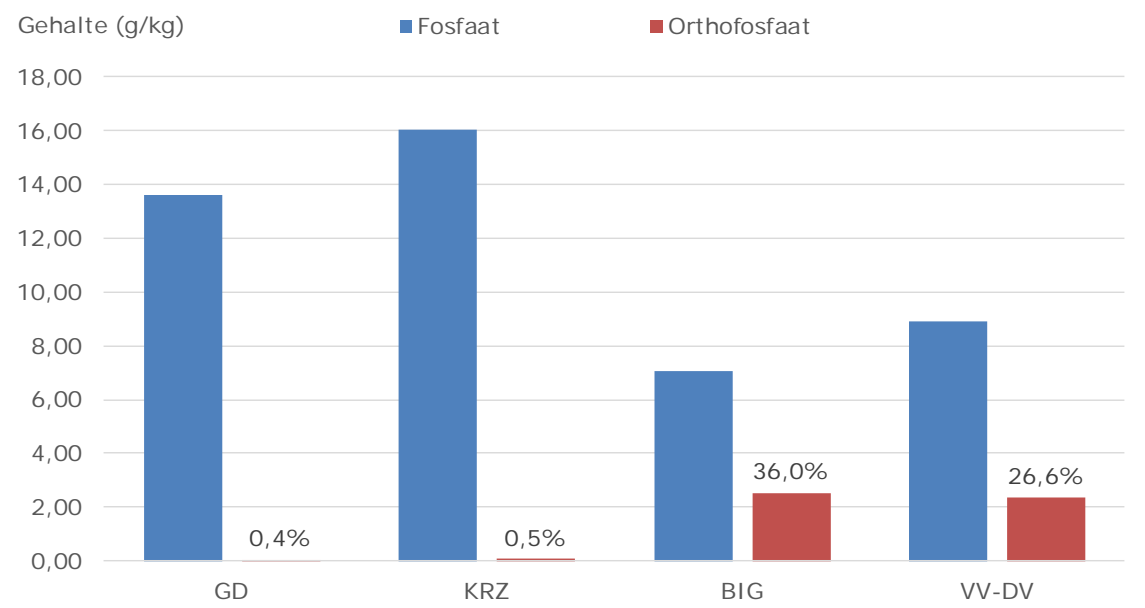

Figuur 9 Fosfaat en orthofosfaat gehalten in de faeces met het aandeel orthofosfaat in het totaal fosfaatgehalte.

Het orthofosfaat gehalte in de faeces van de biggen en van de vleesvarkens op droogvoer lag ongeveer een factor 37 hoger dan in de faeces van de kraamzeugen en guste en dragende zeugen. Tevens lag het ook vele malen hoger dan het gehalte in de drijfmest of gescheiden fracties. Dit zal met name veroorzaakt zijn door een hoog calciumgehalte en hoge $\mathrm{pH}$ in de faeces van de zeugen waardoor orthofosfaat in fosfaatverbindingen zoals calciumfosfaat zit. Tevens lagen de fosfaatgehalten in de faeces van de biggen en de vleesvarkens op droogvoer op circa de helft van het fosfaatgehalten van de faeces afkomstig van de kraamzeugen en guste en dragende zeugen. Dit zal onder andere veroorzaakt worden door een verschil in voersamenstelling en -benutting. Big en vleesvarkens zijn groeiende dieren terwijl zeugen volwassen dieren zijn.

In figuren 10a t/m c staan de belangrijkste relaties m.b.t. fosfaat, orthofosfaat, calcium en magnesium in de faeces weergegeven met indicatieve trendlijnen. Er lijkt sprake te zijn van een negatief verband tussen het orthofosfaat gehalte en het fosfaatgehalte in de faeces op zowel product als op droge stof basis. Tussen het fosfaatgehalte en het calcium- en magnesiumgehalte lijkt er een positief verband te zijn, terwijl voor orthofosfaat er sprake lijkt te zijn van een negatief verband. 

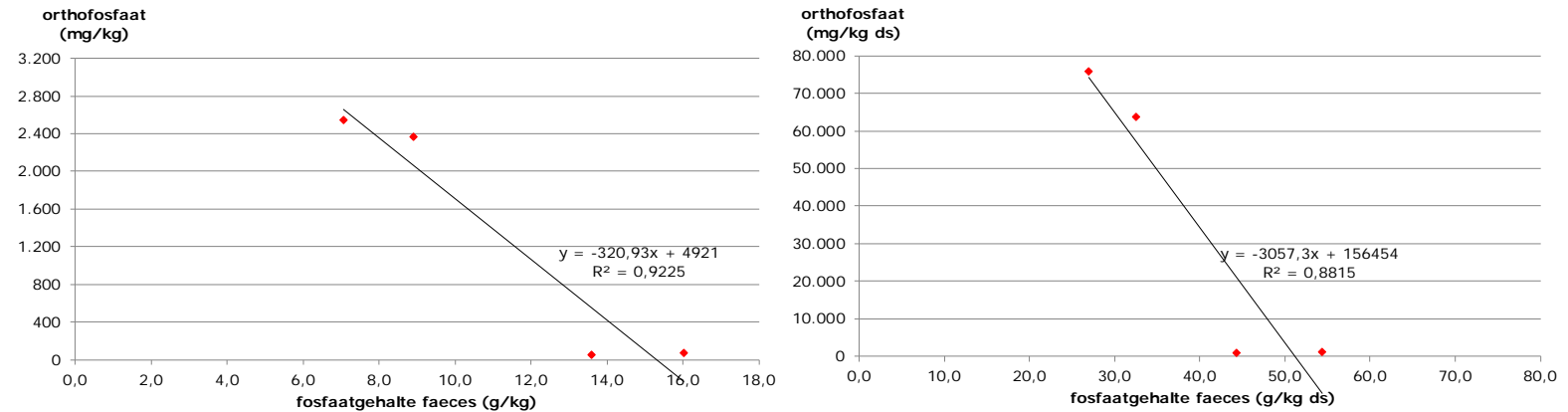

Figuur 10a Het orthofosfaat gehalte in de faeces in relatie tot het fosfaatgehalte in de faeces op product en droge stof basis.
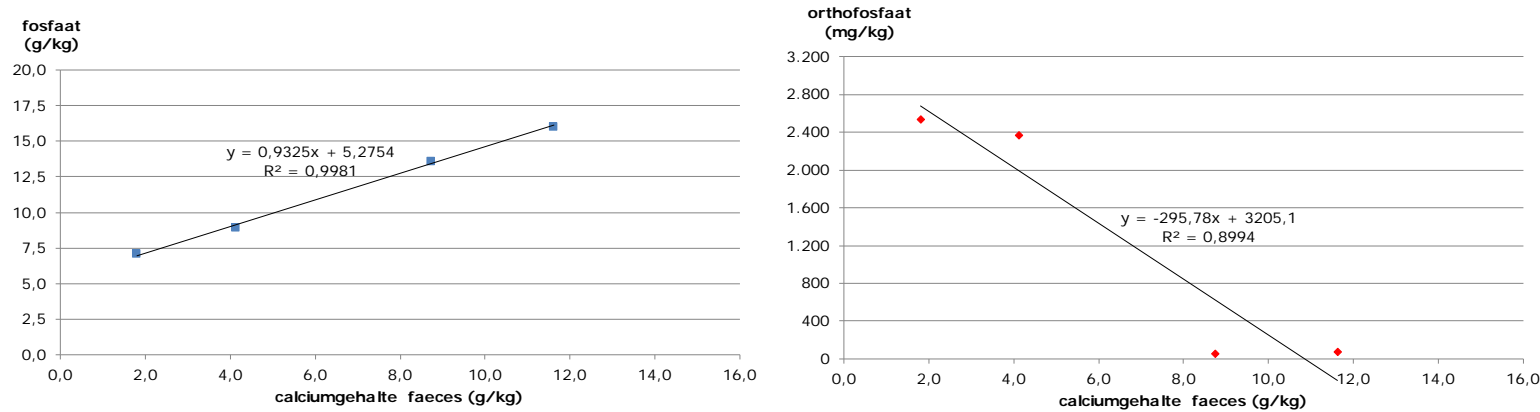

Figuur 10b Het fosfaat en orthofosfaat gehalte in de faeces in relatie tot het calciumgehalte in de faeces.
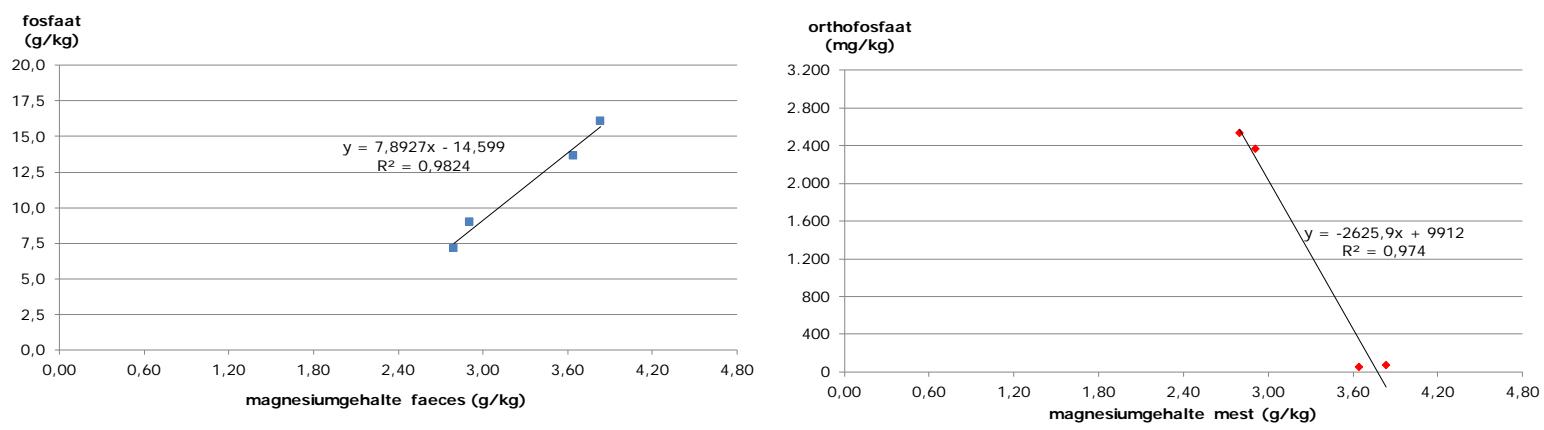

Figuur 10c Het fosfaat en orthofosfaat gehalte in de faeces in relatie tot het magnesiumgehalte in de faeces. 


\subsection{Terugwinning van fosfaat uit de dunne fractie}

In tabel 8 staan de analyseresultaten en gewichten van de verschillende fracties van de proef met het toevoegen van calciumhydroxide aan de dunne fractie afkomstig van de centrifuge weergegeven.

Tabel 8 Analyseresultaten van de dunne fracties afkomstig van de centrifuge en gescheiden fracties na toedienen van calciumhydroxide aan de dunne fracties met de scheidingsrendementen.

\begin{tabular}{|c|c|c|c|c|c|c|c|c|}
\hline \multirow[t]{2}{*}{ Diersoort } & \multirow{2}{*}{$\begin{array}{c}\text { DS } \\
(\mathrm{g} / \mathrm{kg})\end{array}$} & \multirow{2}{*}{$\begin{array}{c}\mathrm{P}_{2} \mathrm{O}_{5} \\
(\mathrm{~g} / \mathrm{kg})\end{array}$} & \multirow{2}{*}{$\begin{array}{l}\text { Ortho- } \mathrm{P}_{2} \mathrm{O}_{5} \\
(\mathrm{mg} / \mathrm{kg})\end{array}$} & \multirow{2}{*}{$\begin{array}{l}\text { pH } \\
(-)\end{array}$} & \multicolumn{4}{|c|}{ Scheidingsrendement ( $\%$ ) } \\
\hline & & & & & Massa & DS & $\mathrm{P}_{2} \mathrm{O}_{5}$ & Ortho- $\mathrm{P}_{2} \mathrm{O}_{5}$ \\
\hline \multicolumn{9}{|c|}{ Dunne fractie } \\
\hline GDZ & 19,8 & 0,55 & 213 & 8,0 & - & - & - & - \\
\hline KRZ & 13,9 & 0,38 & 150 & 7,9 & - & - & - & - \\
\hline BIG & 33,7 & 0,82 & 233 & 8,1 & - & - & - & - \\
\hline VV-DV & 35,3 & 0,91 & 457 & 7,7 & - & - & - & - \\
\hline VV-BV1 & 30,3 & 0,56 & 283 & 8,3 & - & - & - & - \\
\hline VV-BV2 & 30,4 & 0,99 & 426 & 8,6 & - & - & - & - \\
\hline VV-FERM & 41,1 & 0,47 & 47 & 7,9 & - & - & - & - \\
\hline \multicolumn{9}{|l|}{ Sediment } \\
\hline GDZ & 140,8 & 6,95 & n.g. & n.g. & $6 \%$ & $37 \%$ & $72 \%$ & - \\
\hline KRZ & 130,1 & 7,50 & n.g. & n.g. & $4 \%$ & $36 \%$ & $78 \%$ & - \\
\hline BIG & 135,6 & 4,44 & n.g. & n.g. & $13 \%$ & $50 \%$ & $73 \%$ & - \\
\hline VV-DV & 124,3 & 5,83 & n.g. & n.g. & $13 \%$ & $39 \%$ & $80 \%$ & - \\
\hline VV-BV1 & 142,3 & 3,20 & n.g. & n.g. & $8 \%$ & $35 \%$ & $47 \%$ & - \\
\hline VV-BV2 & 148,7 & 7,29 & n.g. & n.g. & $8 \%$ & $35 \%$ & $59 \%$ & - \\
\hline VV-FERM & 145,6 & 4,74 & n.g. & n.g. & $8 \%$ & $26 \%$ & $75 \%$ & - \\
\hline \multicolumn{9}{|c|}{ Centrifugaat } \\
\hline GDZ & 15,4 & 0,18 & 77 & 9,4 & $94 \%$ & $63 \%$ & $28 \%$ & $34 \%$ \\
\hline KRZ & 10,4 & 0,10 & 1 & 9,1 & $96 \%$ & $64 \%$ & $22 \%$ & $1 \%$ \\
\hline $\mathrm{BIG}$ & 21,2 & 0,25 & 133 & 9,5 & $87 \%$ & $50 \%$ & $27 \%$ & $49 \%$ \\
\hline VV-DV & 28,3 & 0,22 & 73 & 9,2 & $87 \%$ & $61 \%$ & $20 \%$ & $14 \%$ \\
\hline VV-BV1 & 24,1 & 0,32 & 245 & 9,5 & $92 \%$ & $65 \%$ & $53 \%$ & $79 \%$ \\
\hline VV-BV2 & 23,7 & 0,43 & 217 & 9,6 & $92 \%$ & $65 \%$ & $41 \%$ & $47 \%$ \\
\hline VV-FERM & 34,8 & 0,14 & 18 & 9,3 & $92 \%$ & $74 \%$ & $25 \%$ & $35 \%$ \\
\hline
\end{tabular}

n.g. = niet gemeten

Uit de resultaten bleek dat gemiddeld $9 \%$ van de massa en $37 \%$ van de droge stof terechtkwam in het sediment. De toevoeging van calciumhydroxide heeft geleid tot lagere fosfaatgehalten in het centrifugaat en hogere fosfaatgehalten in het sediment. Gemiddeld kwam $69 \%$ van het totale fosfaat uit de dunne fractie terecht in het sediment. Van het totale orthofosfaat uit de dunne fractie kwam gemiddeld $37 \%$ terecht in het centrifugaat en daarmee $63 \%$ in het sediment. Dit is $54 \%$ hoger dan het scheidingsrendement voor de massa wat inhoudt dat een aanzienlijk deel van het beschikbare orthofosfaat gereageerd heeft met calcium en in het sediment terecht is gekomen. Tabel 9 toont de fosfaatgehalten in de dikke fractie, dunne fractie en het sediment per kilogram product. Het fosfaatgehalte in het sediment is lager dan in de dikke fractie verkregen na centrifugeren.

Tabel 9 Fosfaatgehalten in dikke fractie, dunne fractie en het sediment verkregen na calciumhydroxide toevoeging in $\mathrm{P}_{2} \mathrm{O}_{5}$ per kg product.

\begin{tabular}{lccc} 
Diersoort & $\begin{array}{c}\text { Dikke fractie } \\
(\mathrm{g} / \mathrm{kg})\end{array}$ & $\begin{array}{c}\text { Dunne fractie } \\
(\mathrm{g} / \mathrm{kg})\end{array}$ & $\begin{array}{c}\text { Sediment } \\
(\mathrm{g} / \mathrm{kg})\end{array}$ \\
\hline GDZ & 22,15 & 0,53 & 6,95 \\
\hline KRZ & 19,47 & 0,37 & 7,50 \\
\hline BIG & 22,33 & 0,76 & 4,44 \\
\hline VV-DV & 17,27 & 0,91 & 5,83 \\
\hline VV-BV1 & 20,28 & 0,54 & 3,20 \\
\hline VV-BV2 & 18,93 & 0,97 & 7,29 \\
\hline VV-FERM & 19,79 & 0,47 & 4,74 \\
\hline
\end{tabular}




\section{$4 \quad$ Discussie}

Bij de scheiding van de kraamzeugenmest met de vijzelpers bleek, zoals verwacht, dat het droge stof en organische gehalte van de drijfmest hoger was dan in de dunne fractie. Echter de mineralengehalten bleken lager te zijn dan in de dunne fractie, want onlogisch is omdat de mineralen zich concentreren in de dikke fractie. De kraamzeugenmest was echter moeilijk te scheiden met de vijzelpers doordat deze heel dun was. Het is niet waarschijnlijk dat de monsters verwisseld zijn aangezien niet alle gehalten onlogisch waren en geen monsterverwisseling in het labotorium is vastgesteld. Het lijkt er daarmee op dat de moeilijke scheiding voor het opmerkelijke resultaat heeft gezorgd.

In de internationale literatuur is nauwelijks vergelijkbaar onderzoek verricht naar het orthofosfaat gehalte is varkensmest. Daarbij komt nog dat in verschillende onderzoeken het orthofosfaat gehalte wordt bepaald door het monster eerst te verdunnen alvorens deze te centrifugeren, filtreren en analyseren (Ndegwa et al., 2001; Ndegwa et al., 2004). Door het monster eerst te verdunnen alvorens te centrifugeren komt orthofosfaat vrijgemaakt uit minerale fosfaatverbindingen waardoor een overschatting van het orthofosfaat gehalte plaatsvindt (Timmerman et al., 2018). Daumer et al. (2008) hebben een vergelijkbare methode toegepast als in dit onderzoek om het gehalte aan orthofosfaat te bepalen. Voor twee zeugenmesten werd een orthofosfaat gehalte van 133 en 169 $\mathrm{mg} / \mathrm{kg}$ gevonden en voor biggenmest $73 \mathrm{mg} / \mathrm{kg}$ wat respectievelijk $4,7 \%, 6,0 \%$ en 3,2\% van de totale hoeveelheid fosfaat was. Deze gehalten zijn wat lager dan wat in deze studie is gevonden.

Door Schoumans et al. (2014; 2017) is het onderzoek gedaan naar winning van fosfaat uit gescheiden varkensmest via twee methoden. In de eerste methode (magnesium-methodiek) werd aan de dunne fractie uit een eenvoudige filtratiescheiding magnesiumchloride toegevoegd om zo magnesium fosfaat mineralen te vormen zoals struviet. In de tweede methode (zuur-base methodiek) werd aan de dikke fractie uit een centrifuge zwavelzuur toegevoegd waarna de aangezuurde dikke fractie werd gescheiden in een fosfaatarme vaste fractie en fosfaatrijke dunne fractie. Aan de fosfaatrijke dunne fractie werd vervolgens calciumhydroxide toegevoegd om het aanwezige fosfaat te precipiteren. Bij de 'zuur-base-methodiek' kon 70-80\% van het fosfaat uit de dikke fractie worden gehaald, terwijl bij de 'magnesium-methodiek' minder fosfaat kon worden gehaald uit de dunne fractie. Bij de 'magnesiummethodiek' bleek het grootste obstakel dat de gevormde kristallen te klein waren om te winnen. De 'zuur-base-methodiek' bleek zowel te werken op laboratoriumschaal als op pilot-schaal. Door de mest aan te zuren wordt orthofosfaat vrijgemaakt uit de fosfaatverbindingen in de mest waardoor een groter deel van het fosfaat kan worden teruggewonnen uit de mest.

In de uitgevoerde studie kwam een groot verschil in orthofosfaat gehalte in de faeces naar voren. De grootste oorzaak hiervan zal het verschil in pH zijn. Zo laat Schoumans et al. (2017) een groot effect van $\mathrm{pH}$ zien bij varkensmest. Bij een $\mathrm{pH}$ boven de 7 was er zeer weinig orthofosfaat, bij 6,5 iets meer en tussen pH 6 en 5 een sterke toename in orthofosfaat. In deze studie kon het effect van pH en calcium niet van elkaar worden onderscheiden. In de faeces van de zeugen zat veel calcium zodat er veel calciumfosfaat gevormd kan worden wat bij hoge pH slecht in oplossing komt. Daarnaast kan er verschil zijn in bufferend vermogen van de $\mathrm{pH}$ tussen de faeces van de zeugen, biggen en vleesvarkens. 


\section{$5 \quad$ Conclusies}

- In de drijfmest varieerde het orthofosfaat gehalte van 69 tot $528 \mathrm{mg} / \mathrm{kg}$ en bedroeg 3,0 tot $13,7 \%$ van de totale hoeveelheid fosfaat in de drijfmest.

- In de dunne fracties afkomstig van de vijzelpers varieerde het orthofosfaat gehalte van 64 tot 517 $\mathrm{mg} / \mathrm{kg}$ en bedroeg 2,6 tot $17,1 \%$ van de totale hoeveelheid fosfaat in de dunne fractie. In de dunne fracties afkomstig van de centrifuge varieerde het orthofosfaat-gehalte van 41 tot 491 $\mathrm{mg} / \mathrm{kg}$ en bedroeg 8,9 tot $53,8 \%$ van de totale hoeveelheid fosfaat in de dunne fractie.

- In de dikke fracties is het orthofosfaat gehalte berekend, omdat analyseren zonder verdunning niet mogelijk bleek. Het berekende orthofosfaat gehalte in de dikke fractie afkomstig van de vijzelpers varieerde van 98 tot $783 \mathrm{mg} / \mathrm{kg}$ en bedroeg 2,3 tot 13,2\% van de totale hoeveelheid fosfaat in de dikke fractie. In de dikke fracties afkomstig van de centrifuge varieerde het berekende orthofosfaat gehalte van 70 tot $752 \mathrm{mg} / \mathrm{kg}$ en bedroeg 0,4 tot 4,4\% van de totale hoeveelheid fosfaat in de dikke fractie.

- In de faeces was het orthofosfaat gehalte gemiddeld $67 \mathrm{mg} / \mathrm{kg}$ bij kraamzeugen en guste en dragende zeugen, en gemiddeld $2459 \mathrm{mg} / \mathrm{kg}$ bij biggen en vleesvarkens op droogvoer. De $\mathrm{pH}$ van de faeces van de biggen en vleesvarkens op droogvoer lag beneden de 5,8 terwijl dit bij de zeugen boven de 6,6 lag.

- Na toevoeging van calciumhydroxide aan dunne fracties afkomstig van de centrifuge kwam gemiddeld $9 \%$ van de massa, $37 \%$ van de droge stof, $69 \%$ van het totaal fosfaat en $63 \%$ van de orthofosfaat terecht in het sediment.

- Het orthofosfaat gehalte in de varkensmest, dunne en dikke fracties, en faeces van de zeugen was niet hoog genoeg om dit te gaan winnen uit de mest en mestfracties zonder aanvullende maatregelen, zoals aanzuren om meer orthofosfaat vrij te maken uit de aanwezige minerale fosfaatverbindingen. Bij faeces van de biggen en vleesvarkens op varkens lag het orthofosfaat gehalte op gemiddeld $2459 \mathrm{mg} / \mathrm{kg}$ waarmee ongeveer 31\% van het aanwezige fosfaat potentieel uit de faeces zou gewonnen kunnen worden. 


\section{Literatuur}

Daumer, M., F. Béline, M. Spérandio en C. Morel. 2008. Relevance of a perchloric acid extraction scheme to determine mineral and organic phosphorus in swine slurry. Bioresource Technology 99: 1319-1324.

Ndegwa, P.M., J. Zhu en A. Luo. 2001. Effect of batch aeration-treatment on the solubility of phosphorus in pig manure. Journal of Agriculture Engineering Research 80 (4): 365-371.

Ndegwa, P.M., J. Zhu, A. Luo en D.W. Hamilton. 2004. Enhanced phosphorous removal from swinenursery manure in aerated batch reactors. Transactions of the ASAE 46 (3): 797-803.

Schoumans, O.F., P.A.I Ehlert, J.A. Nelemans, W. van Tintelen, W.H. Rulkens en O. Oenema, 2014. Exporative study of phosphorous recovery from pig slurry. Alterra Wageningen UR, Wageningen. Report 2514.

Schoumans, O.F., P.A.I Ehlert, I.C. Regelink, J.A. Nelemans, I.G.A.M Noij, W. van Tintelen en W.H. Rulkens, 2017. Chemical phosphorus recovery from animal manure and digestate: laboratory and pilot experiments. Wageningen Environmental Research, Wageningen. Report 2849.

Timmerman, M., I. Regelink, N. Verdoes, G.C.C. Kupers en K. Blanken. 2018. Winningspotentieel van orthofosfaat uit melkveemest. Wageningen Livestock Research, Wageningen. Rapport in druk.

Van Middelkoop, J., W. van Dijk, H. van Reuler, F. de Ruijter en B. Smit. 2015. Fosforstromen door landbouw, industrie, huishoudens en afval. V-focus 12 (4):36-38. 


\section{Bijlage 1 Fosforstromen in Nederland}

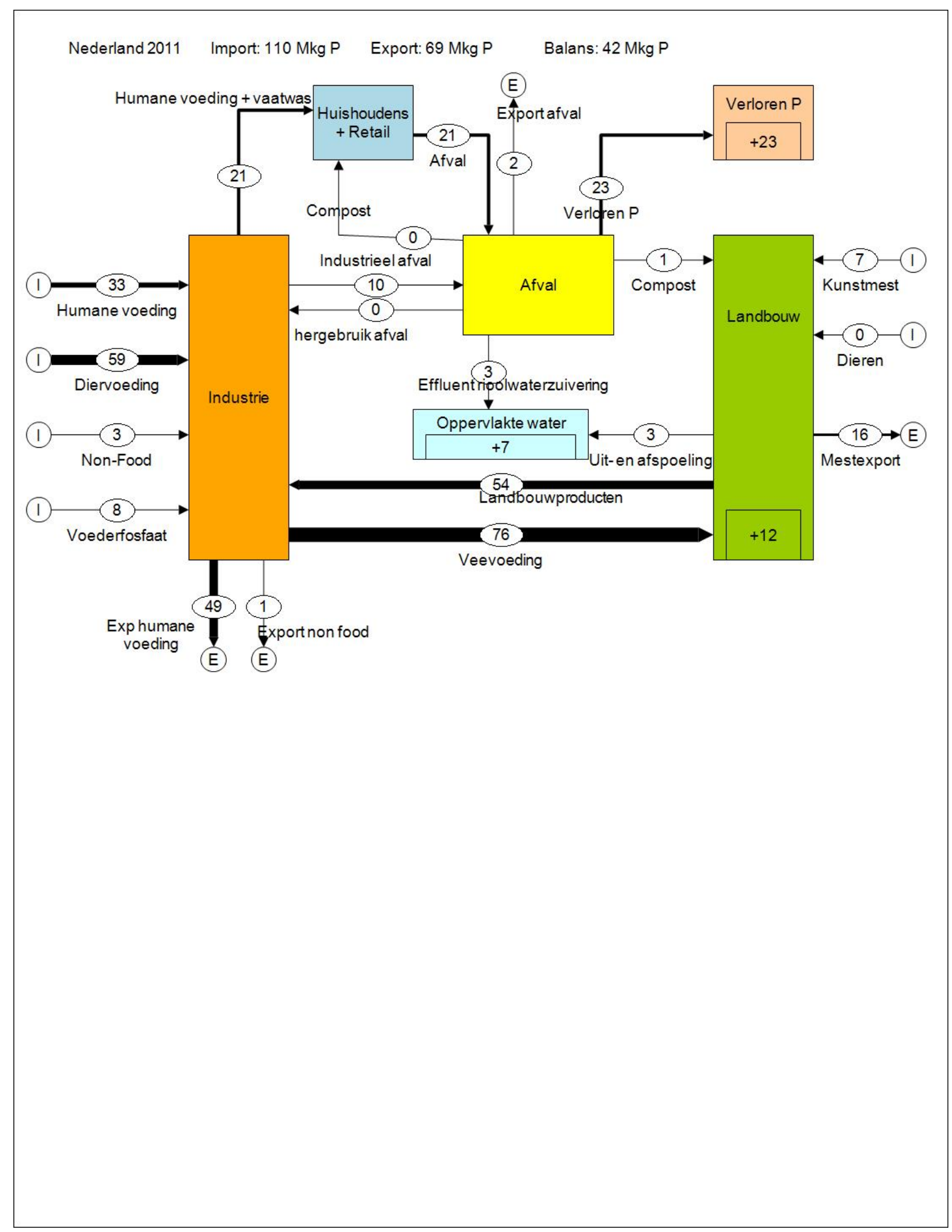

Figuur 1 Fosforstromen in industrie, landbouw, huishoudens, afval en oppervlaktewater in 2011 (miljoen kg P per jaar) (Van Middelkoop et al., 2015). 
Landbouw 2011 Import: 85 Mkg P Export: 73 Mkg P Balans: 12 Mkg P

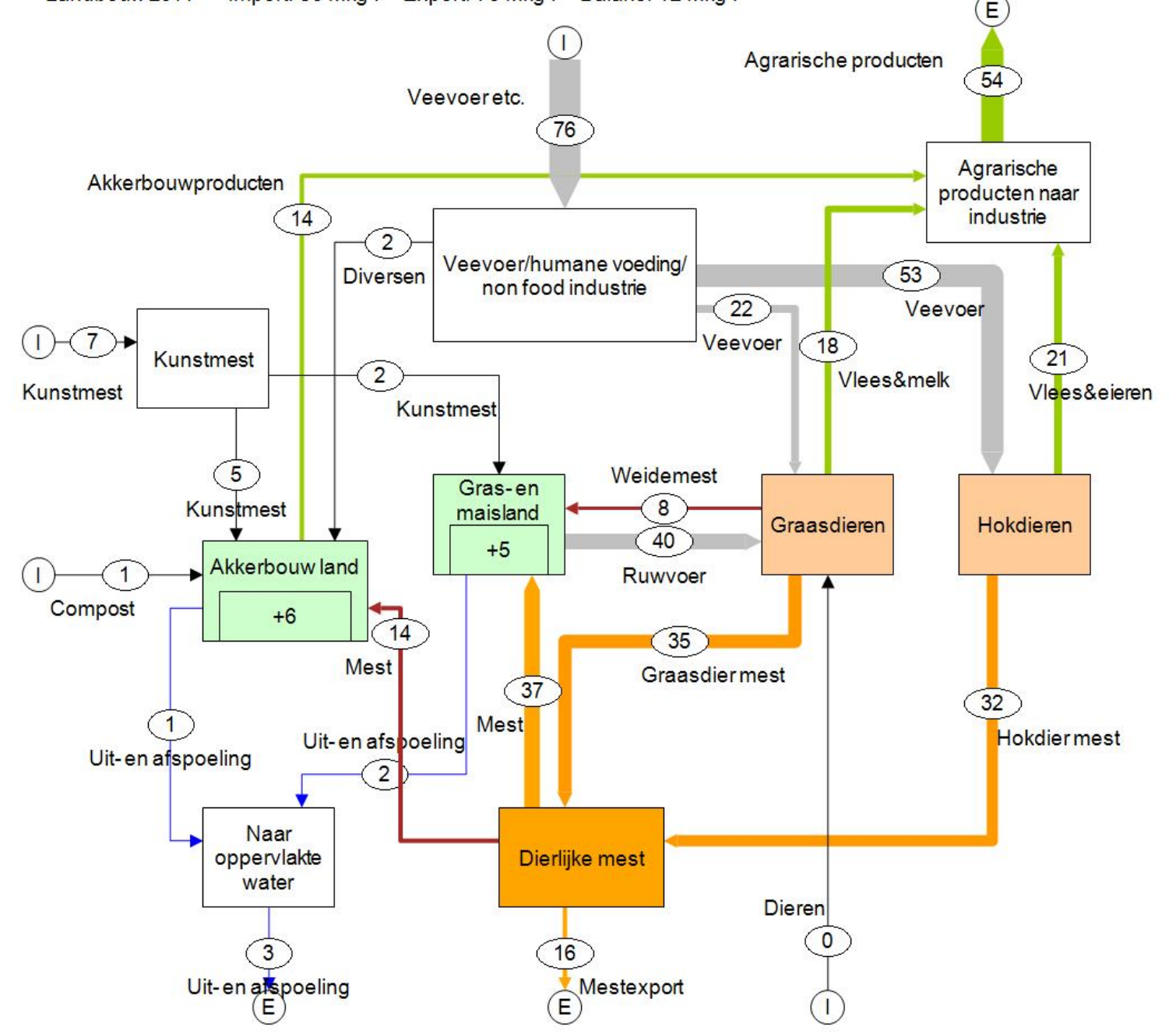

Figuur 2 Fosforstromen in de landbouw in 2011 (miljoen kg P per jaar) (Van Middelkoop et al., 2015). 


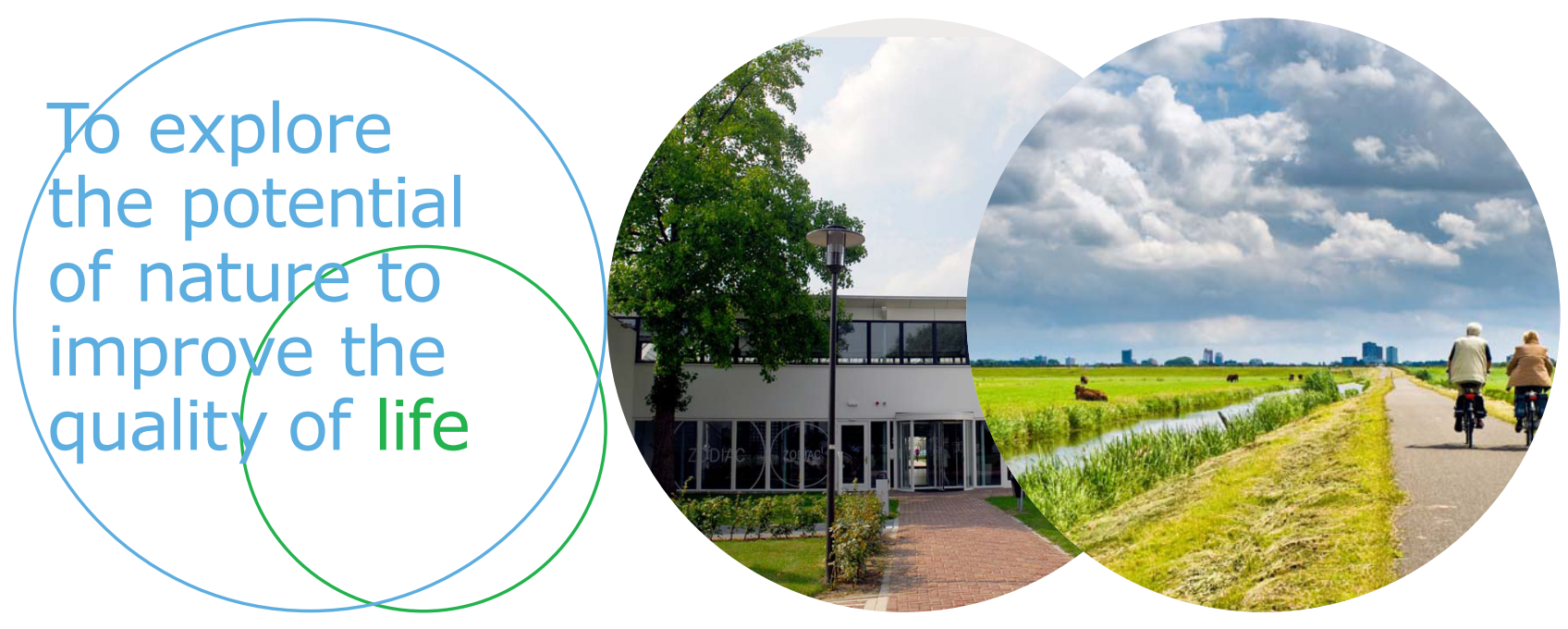

Wageningen Livestock Research Postbus 338

Wageningen Livestock Research ontwikkelt kennis voor een zorgvuldige en 6700 AH Wageningen

T 0317483953

renderende veehouderij, vertaalt deze naar praktijkgerichte oplossingen en innovaties, en zorgt voor doorstroming van deze kennis. Onze wetenschappelijke

E info.livestockresearch@wur.nl www.wur.nl/ livestock-research kennis op het gebied van veehouderijsystemen en van voeding, genetica, welzijn en milieu-impact van landbouwhuisdieren integreren we, samen met onze klanten, tot veehouderijconcepten voor de $21 \mathrm{e}$ eeuw.

De missie van Wageningen University \& Research is 'To explore the potential of nature to improve the quality of life'. Binnen Wageningen University \& Research bundelen 9 gespecialiseerde onderzoeksinstituten van Stichting Wageningen Research en Wageningen University hun krachten om bij te dragen aan de oplossing van belangrijke vragen in het domein van gezonde voeding en leefomgeving. Met ongeveer 30 vestigingen, 6.500 medewerkers en 10.000 studenten behoort Wageningen University \& Research wereldwijd tot de aansprekende kennisinstellingen binnen haar domein. De integrale benadering van de vraagstukken en de samenwerking tussen verschillende disciplines vormen het hart van de unieke Wageningen aanpak. 